\title{
Lidar signal simulation for the evaluation of aerosols in chemistry transport models
}

\author{
S. Stromatas ${ }^{1}$, S. Turquety ${ }^{2}$, L. Menut ${ }^{1}$, H. Chepfer ${ }^{2}$, J. C. Péré ${ }^{3}$, G. Cesana ${ }^{2}$, and B. Bessagnet ${ }^{4}$ \\ ${ }^{1}$ Institut P.-S. Laplace, Laboratoire de Météorologie Dynamique, CNRS, UMR8539, Ecole Polytechnique, Palaiseau, France \\ ${ }^{2}$ Institut P.-S. Laplace, Laboratoire de Météorologie Dynamique, Université Pierre et Marie Curie-Paris 06, 75252 Paris \\ Cedex 05, France \\ ${ }^{3}$ Laboratoire d'Optique Atmosphérique, Université Lille 1, 59655 Villeneuve d'Ascq, France \\ ${ }^{4}$ INERIS, Institut National de l'Environnement Industriel et des Risques, Parc technologique ALATA, 60550 Verneuil en \\ Halatte, France
}

Correspondence to: S. Stromatas (stavros.stromatas@1md.polytechnique.fr)

Received: 10 May 2012 - Published in Geosci. Model Dev. Discuss.: 25 June 2012

Revised: 3 October 2012 - Accepted: 1 November 2012 - Published: 7 December 2012

\begin{abstract}
We present an adaptable tool, the OPTSIM (OPTical properties SIMulation) software, for the simulation of optical properties and lidar attenuated backscattered profiles $\left(\beta^{\prime}\right)$ from aerosol concentrations calculated by chemistry transport models (CTM). It was developed to model both Level 1 observations and Level 2 aerosol lidar retrievals in order to compare model results to measurements: the level 2 enables to estimate the main properties of aerosols plume structures, but may be limited due to specific assumptions. The level 1, originally developed for this tool, gives access to more information about aerosols properties $\left(\beta^{\prime}\right)$ requiring, at the same time, less hypothesis on aerosols types. In addition to an evaluation of the aerosol loading and optical properties, active remote sensing allows the analysis of aerosols' vertical structures. An academic case study for two different species (black carbon and dust) is presented and shows the consistency of the simulator. Illustrations are then given through the analysis of dust events in the Mediterranean region during the summer 2007. These are based on simulations by the CHIMERE regional CTM and observations from the CALIOP space-based lidar, and highlight the potential of this approach to evaluate the concentration, size and vertical structure of the aerosol plumes.
\end{abstract}

\section{Introduction}

Aerosols are key for air quality monitoring due to their impact on human health (Pope et al., 2002), visibility (Wang et al., 2009) and biogeochemical cycles (Andreae and Merlet, 2001; Shinn et al., 2000). Through their influence on the Earth radiative budget and cloud microphysics, they also impact meteorological conditions and climate (Forster et al., 2007). In addition to a local effect, aerosol plumes may be transported for long distances with significant direct and indirect effects on atmospheric composition (Monks et al., 2009) at regional (Bessagnet et al., 2008) to hemispheric scales (Stohl et al., 2002).

While their importance is fully recognised, the assessment of their impact remains poorly quantified due to numerous uncertainties on their emissions, properties and evolution during transport. Model inter-comparisons, such as those of the AeroCom project (e.g. Textor et al., 2007), reveal the need to better quantify the large variabilities in terms of size, morphology and chemical composition of aerosols. More specifically, key species like black carbon (e.g. Koch et al., 2009), mineral dust (e.g. Huneeus et al., 2011) or secondary organic aerosols (e.g. Hallquist et al., 2009) remain generally inadequately modelled, leading to an incomplete description of the aerosol budgets in the atmosphere.

The simulation of the long-range transport of aerosol plumes requires an accurate representation of their vertical structure (e.g., location, spread). It affects aerosol lifetime 
(e.g. Keating and Zuber, 2007) and, as a result, surface concentrations. Moreover, it has an impact on aerosol-cloud interactions (e.g. Waquet et al., 2009, and references therein) and on aerosol radiative forcing (e.g. Zarzycki and Bond, 2010; Zhu et al., 2007).

The availability of satellite observations has greatly enhanced our ability to evaluate models. They complement surface and in situ measurements by providing a large scale context. In particular, the A-Train constellation of satellites allows simultaneous measurements from complementary instrumentation. Passive remote sensors (MODIS on board AQUA, TERRA or POLDER-3 on board PARASOL) allow the analysis of total aerosol loading through aerosol optical depth (AOD) retrieval (Remer et al., 2005; Tanré et al., 2011) with good spatiotemporal resolution (almost global daily with pixel size of $\sim 10 \mathrm{~km}$ ). These satellite observations have been shown to offer useful insight into the spatial and temporal variability of particulate matter by both biogenic (e.g. Liu et al., 2008) and anthropogenic sources (e.g. Kaufman et al., 2005). Recent studies have shown their ability to constrain emissions using inverse modelling to estimate their sources (e.g. Dubovik et al., 2008), global budgets (Heald et al., 2010), and surface particulate matter (PM) concentrations (van Donkelaar et al., 2006). These observations have also been widely used for the analysis of longrange transport pathways (Hodzic et al., 2007; Ridley et al., 2012) and regional simulations of aerosols through their optical properties (Péré et al., 2009). However, passive satellites provide column-integrated aerosol properties. Thus, they offer limited information on the vertical distribution of aerosols within the atmosphere.

The complementary active remote-sensing observations of the Cloud-Aerosol Lidar with Orthogonal Polarisation (CALIOP) lidar in space (on board CALIPSO, also part of the A-Train) provide valuable information on the vertical distribution of aerosols (Winker et al., 2009). They were used in several recent studies for the evaluation of chemistry transport model (CTM) simulations (e.g. Yu et al., 2010; Ford and Heald, 2012; Ridley et al., 2012). The classic approach for comparing model simulations and satellite observations is using the level 2 (L2) retrievals, which are derived from the Level 1 (L1) observations. The reliability of L2 retrievals is constantly improving (V3 data products have considerably improved compared to the $\mathrm{V} 2$ release), and these data have proven to be very useful for analysing aerosol-related pollution events. However, it is a well-documented fact that they are prone to uncertainties (Liu et al., 2009; Omar et al., 2010; Young and Vaughan, 2009; Winker et al., 2009). More specifically, the accuracy of these products depends to a large extent on the uncertainties of each step (algorithm) in the processing chain. A key parameter that is used to derive L2 products (backscatter and extinction coefficients) from attenuated backscatter profiles (L1 data) is the extinction-to-backscatter ratio (lidar ratio). The mean values used are based on prescribed bi-modal size distributions and characteristic com- plex refractive indices according to the observed natural variability for each aerosol species. The estimated values may diverge from the correct values if the identified layer is wrongly classified (e.g., dense smoke aerosol layers can be misclassified as clouds, Liu et al., 2009) or if incorrect estimates of the aerosol type (e.g., dust misclassified as polluted dust, Omar et al., 2010) are used (Young and Vaughan, 2009). Natural variability can also be the cause of an erroneous estimation of the lidar ratio which will, of course, result into a biased retrieval.

For example, although CALIPSO L2 dust observations are found to exhibit reasonable agreement with ground measurements, some considerable discrepancies still exist in lidar ratio values between CALIPSO and ground measurements. More specifically, the range of different lidar ratio values in the CALIPSO Lidar Ratio selection algorithm is rather narrow compared to the values reported in the literature (e.g. Schuster et al., 2012, and references therein).

Since aerosol type and properties assumptions in the retrievals may not be consistent with the model simulations, using comparisons to L2 retrievals for model evaluation may be difficult to interpret. To avoid these complications, we provide a methodology for direct comparisons to L1 observations of the total attenuated backscattered profiles from the CALIOP level 1B V3.01 dataset.

This approach has already been applied for comparisons between airborne lidar measurements and CALIOP for the analysis of field campaigns (de Villiers et al., 2010), for comparisons between model and surface lidar observations (Hodzic et al., 2004), CALIOP observations of clouds (Chepfer et al., 2008) and dust aerosols (Vuolo et al., 2009). Modelderived attenuated backscatter profiles were also used (Generoso et al., 2008) to study dust outflow over the Atlantic, however, their method is based on estimations of lidar ratio values. The OPTSIM simulator presented here is a flexible post-processing tool for chemistry transport models that generalises this methodology for the simulation of all aerosol type. For comparisons to models, the L2 and L1 profiles that would be observed by a lidar in the same atmospheric conditions as those predicted by the model are calculated.

After a general description of OPTSIM (Sect. 2), we present a test on an academic case study in Sect. 3. The simulator is then applied on a real test case. We use the information provided by the CALIOP observations for the analysis of dust events in the Euro-Mediterranean region, regularly affected by long-range transport of Saharan dust (Querol et al., 2009; Lelieveld, 2002). The observations used are described in Sect. 4 and the CHIMERE CTM in Sect. 5. The results and discussion are presented in Sect. 6. 


\section{Modelling aerosol optical properties}

\subsection{Aerosol optical scheme}

The first step for modelling aerosol optical properties was to develop an aerosol optical scheme dedicated to the evaluation of vertically integrated particle loading (optical depth) as presented in (Péré et al., 2010). This module was specifically designed to calculate aerosol properties directly comparable to AERONET data and satellite retrievals (L2 products). It provides maps of aerosol optical depth (AOD) and other optical properties, such as the Single Scattering Albedo (SSA) and the asymmetry factor $(g)$, based on simulated atmospheric chemical concentration fields.

The AOD or $\tau_{\text {ext }}$, which represents the attenuation of the incident solar radiation light by atmospheric particles, depends on the wavelength $(\lambda)$. For a layer thickness $\Delta z$, it is calculated as:

$\tau_{\text {ext }}(\lambda, z)=\int_{\Delta z} \sigma_{p}^{\text {ext }}\left(\lambda, z^{\prime}\right) \mathrm{d} z^{\prime}$

This requires the calculation of the extinction coefficient (by particles), $\sigma_{p}^{\mathrm{ext}}(z, \lambda)\left[\mathrm{m}^{-1}\right]$ as:

$\sigma_{p}^{\mathrm{ext}}(z, \lambda)=\int_{R_{\min }}^{R_{\max }} \pi R^{2} Q_{\mathrm{ext}}(\eta, R, \lambda) \cdot N_{p}(R, z) \mathrm{d} R$

where $Q_{\text {ext }}$ is the extinction efficiency, depending on the refractive index $(\eta)$, the particles radius $(R)$ and the wavelength $(\lambda) . N_{p}$ represents the particle concentration in number $\left(\mathrm{m}^{-3}\right)$. The complex refractive indices and density values are taken from the ADIENT/APPRAISE technical report (http://www.met.reading.ac.uk/adient/).

The effect of relative humidity on the size of water-soluble aerosols and, therefore, on the refractive index is accounted for by using a growth model as described in Hänel, 1976. A mean particle density is similarly defined. Finally, in this study, we consider a homogeneous internal mixing of the different chemical species, but a core-shell mixing can also be chosen (user's specifications). For the case of a homogeneous ensemble of spheres, the optical properties for the particles considered are computed using a Mie code de Rooij and van der Stap, 1984 while for the core-shell mixing scenario, the Wiscombe Mie code for coated spheres is used based on the formulas presented in (Toon and Ackerman, 1981). Nonsphericity of particles such as mineral dust is theoretically and experimentally identified as a source of bias in simulated aerosol optical properties (e.g. Dubovik et al., 2002b) and should be considered cautiously when interpreting the results. A preliminary analysis of the associated uncertainties is presented in Sect. 3.1.4.

Finally, note that this version of the code is developed for a CTM using a sectional representation of the aerosols population. The size distribution is represented by size sections
Table 1. List of variables required as input to the OPTSIM software and their corresponding name to be read in a netCDF input file for the default version of the code. $N_{z}$ corresponds to the number of vertical layers in the profiles, $N_{b}$ to the number of size bins and $N_{\text {obs }}$ to the number of observations to be processed.

\begin{tabular}{|c|c|c|c|}
\hline \multirow{2}{*}{$\begin{array}{l}\text { Variable } \\
\text { Time }\end{array}$} & \multicolumn{2}{|c|}{ Data and dimensions } & \multirow{2}{*}{$\begin{array}{l}\text { Units } \\
\mathrm{h}\end{array}$} \\
\hline & Time & $\left(N_{\text {obs }}\right)$ & \\
\hline Longitude & lon & $\left(N_{\text {obs }}\right)$ & degrees \\
\hline Latitude & lat & $\left(N_{\text {obs }}\right)$ & degrees \\
\hline \multicolumn{4}{|l|}{ Meteorology } \\
\hline Temperature & temp & $\left(N_{\mathrm{obs}} \times N_{z}\right)$ & $\mathrm{K}$ \\
\hline Air density & airmloc & $\left(N_{\text {obs }} \times N_{z}\right)$ & molecules $\mathrm{cm}^{-3}$ \\
\hline Relative humidity & rh & $\left(N_{\text {obs }} \times N_{z}\right)$ & $\% / 100$ \\
\hline Altitude & hlay & $\left(N_{\mathrm{obs}} \times N_{z}\right)$ & $\mathrm{m}$ \\
\hline \multicolumn{4}{|c|}{ Atmospheric composition } \\
\hline Concentration & \multicolumn{2}{|c|}{ conc $\left(N_{\mathrm{obs}} \times N_{z} \times N_{b}\right)$} & $\mu \mathrm{g} \mathrm{m}^{-3}$ \\
\hline Cut-off diameters & cut_off_d & meters $\quad\left(N_{b}\right)$ & $\mathrm{m}$ \\
\hline
\end{tabular}

(bins). Each bin corresponds to a specific diameter range while the cut-off diameters are provided for each bin. This can be modified according to the model configuration. The aerosols size distribution is interpolated to a finer resolution to ensure the best integration as possible where the aerosol concentration number is optically active.

\subsection{Lidar signal analysis and modelling}

In this section, we present in more detail a new application included in the simulator: the modelling of the L1 lidar signal. A general overview of the lidar signal modelling is displayed in Fig. 1. The first column represents a model column, where aerosol concentrations $\left(c_{i}\right)$ are available in grid cells for several model levels $\left(z_{i}\right)$. This leads to a vertical concentration profile, where each $c_{i}$ concentration represent the mean value between $z_{i-1}$ and $z_{i}$ ( $z_{0}$ representing the ground). Based on this concentration profile, we simulate the lidar signal that would be observed by a lidar in space (third column) or by a ground based lidar (fourth column).

The calculation of the lidar signal from simulated aerosol concentration fields requires some additional parameters than those used for the AOD. These parameters, mainly meteorological, are listed in Table 1.

The simulation of L1 lidar profiles requires the calculation of the backscatter coefficient, $\beta$ (in $\mathrm{km}^{-1} \mathrm{sr}^{-1}$ ) which is directly comparable with the L2 backscatter coefficient of CALIOP. It is computed as:

$\beta_{\text {sca }}=\sigma_{p}^{\mathrm{sca}}(z, \lambda) \cdot P_{\pi} / 4 \pi$

where $\sigma_{p}^{\text {sca }}(z, \lambda)$ is the scattering coefficient (cf. Eq. 2) and $P_{\pi} / 4 \pi$ is the backscatter-to-extinction ratio.

In order to efficiently compare modelled and measured lidar profiles, the simulator is designed to also calculate the Attenuated Scattering Ratio, $R^{\prime}(z)$. By definition, $R^{\prime}(z)$ is 

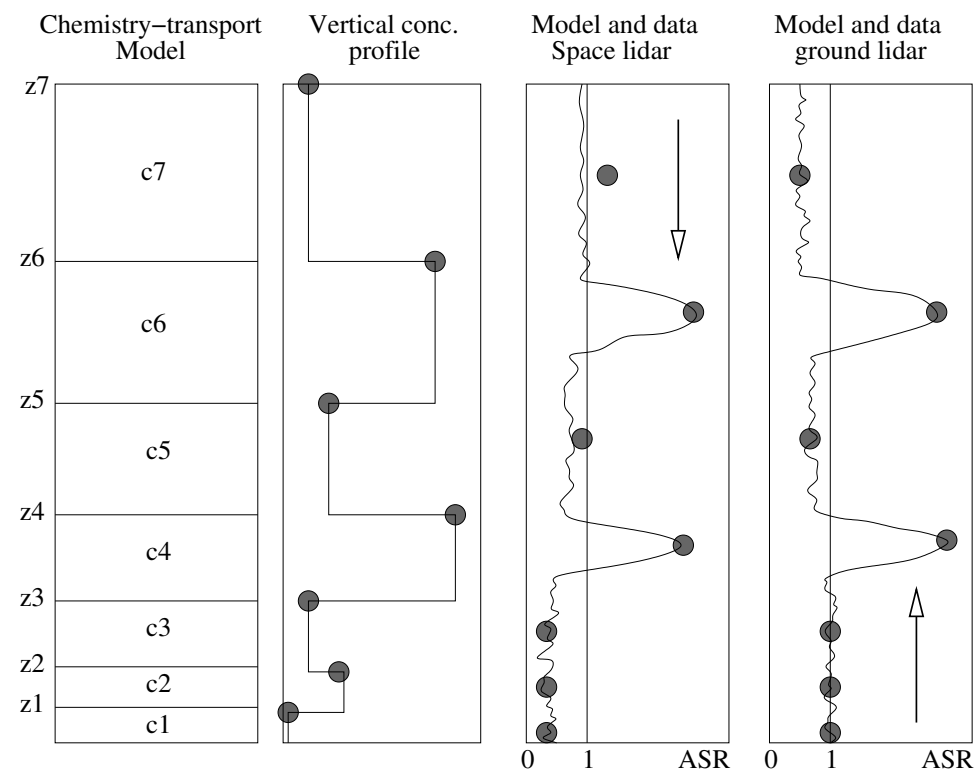

Fig. 1. Overview of the comparison methodology: example of the modelled Attenuated Scattering Ratio (ASR or $\left.R^{\prime}(z)\right)$ estimation from initial concentration profiles (middle-left panel) on a specific model vertical grid (left panel) in the case of a space lidar (middle-right panel) or a ground lidar (right panel). The grey dots correspond to the value reported in the model simulation.

equal to 1 in absence of aerosols/clouds and when the signal is not attenuated. In the presence of aerosols, $R^{\prime}(z)$ will generally be greater than one, however, this value may vary as a function of the quantity and attenuation properties of the aerosol layer. Following Winker et al. (2009), this ratio is expressed as:

$R^{\prime}(z)=\frac{\beta^{\prime}(z)}{\beta_{\mathrm{m}}^{\prime}(z)}$

where

$$
\begin{aligned}
& \beta^{\prime}(z, \lambda)=\left[\frac{\sigma_{\mathrm{m}}^{\mathrm{sca}}(z, \lambda)}{S_{\mathrm{m}}(z, \lambda)}+\frac{\sigma_{\mathrm{p}}^{\mathrm{sca}}(z, \lambda)}{S_{\mathrm{p}}(z, \lambda)}\right] \\
& \cdot \exp \left(-2\left[\int_{z}^{\mathrm{TOA}} \sigma_{\mathrm{m}}^{\text {ext }}\left(z^{\prime}, \lambda\right) \mathrm{d} z^{\prime}+\eta^{\prime} \int_{z}^{\mathrm{TOA}} \sigma_{\mathrm{p}}^{\mathrm{ext}}\left(z^{\prime}, \lambda\right) \mathrm{d} z^{\prime}\right]\right)
\end{aligned}
$$

and

$\beta_{\mathrm{m}}^{\prime}(z, \lambda)=\frac{\sigma_{\mathrm{m}}^{\mathrm{sca}}(z, \lambda)}{S_{\mathrm{m}}(z, \lambda)} \cdot \exp \left(-2 \int_{z}^{\mathrm{TOA}} \sigma_{\mathrm{m}}^{\mathrm{ext}}\left(z^{\prime}, \lambda\right) \mathrm{d} z^{\prime}\right)$

$\beta^{\prime}(z, \lambda)$ and $\beta_{\mathrm{m}}^{\prime}(z, \lambda)$ are, respectively, the total and molecular attenuated backscatter signal. $\sigma_{\mathrm{p}}^{\text {sca/ext }}(z, \lambda)$ and $\sigma_{\mathrm{m}}^{\mathrm{sca} / \mathrm{ext}}(z, \lambda)$ are the extinction/scattering coefficients for particles and molecules (in $\mathrm{km}^{-1}$ ). $S_{\mathrm{m}}$ (respectively $S_{\mathrm{p}}$ ) is the molecular (respectively particular) extinction-to-backscatter ratio (in sr).
Finally, $\eta^{\prime}(z)$ represents multiple scattering and $z$ represents the distance between the emitter and the studied point. Note that for the case of a space lidar the integration begins from the top of the atmosphere (TOA) while for a ground lidar the integration begins from 0 (ground level) to $z$.

The molecular contribution $\left(\sigma_{\mathrm{m}}\right.$ and $\left.S_{\mathrm{m}}\right)$ is calculated theoretically. In order to remain consistent with the observations, we have implemented in OPTSIM the same equation as the one used to derive the molecular backscattering coefficient for producing the CALIOP attenuated backscatter profiles (Hostetler et al., 2006). When the vertical distribution of pressure $(P)$ and temperature $(T)$ is known, the molecular backscattering coefficient can be expressed as:

$\sigma_{\mathrm{m}}^{\mathrm{sca}}=\frac{P}{k_{\mathrm{B}} T} \cdot \frac{S_{\mathrm{sca}, \mathrm{mol}}(\pi)}{S_{\mathrm{m}}}$

with $k_{\mathrm{B}}$ being the Boltzmann constant and $s_{\mathrm{sca} \text {,mol }}$ the molecular scattering cross section (in $\mathrm{m}^{2}$ ), given by:

$s_{\text {sca, } \text { mol }}=4.5102 \cdot 10^{-31} \cdot\left(\frac{\lambda}{0.55}\right)^{-4.025-0.05627 \cdot(\lambda / 550)-1.647}$

Note that $S_{\mathrm{m}}=(8 \pi / 3) k_{\mathrm{bw}}(\lambda)$ where the dispersion of the refractive index and King factor of air are quantified by $k_{\mathrm{bw}}$.

The molecular extinction coefficient $\sigma_{\mathrm{m}}^{\text {ext }}$ is given as a function of $\sigma_{\mathrm{m}}^{\text {sca }}$ :

$\sigma_{\mathrm{m}}^{\mathrm{ext}}=\frac{8 \pi}{3} \cdot \sigma_{\mathrm{m}}^{\mathrm{sca}}$ 
The contribution of particulate matter $\left(\sigma_{\mathrm{p}}\right.$ and $\left.S_{\mathrm{p}}\right)$ can be written as a function of the PM concentration $\left(N_{\mathrm{p}}\right.$ in $\left.\mathrm{m}^{-3}\right)$ and on the particle scattering/extinction efficiency ( $\left.Q_{\text {sca/ext }}\right)$ which depends on the refractive index, the size of particles and the wavelength $(\lambda)$ (cf. Eq. 2).

Note that multiple scattering effects are not taken into account here ( $\eta$ is set to 1 in Eq. 5). The single scattering approximation is adequate for small optical depths and nonabsorbing aerosols in passive remote sensing (e.g. Gordon, 1997). However, large scattering particles (e.g., mineral dust) could lead to non-negligible multiple scattering effects that may need to be taken into account especially in active remote sensing (e.g. Wandinger et al., 2010). Uncertainties arising from this approximation are evaluated in Sect. 3.1.4.

Finally, we also simulate the color ratio $\left(\chi^{\prime}\right)$ which corresponds to the ratio between two lidar profiles observed simultaneously at two different wavelengths $\left(\lambda_{1}=1064 \mathrm{~nm}\right.$ and $\left.\lambda_{2}=532 \mathrm{~nm}\right)$ :

$\chi^{\prime}(z)=\frac{\beta_{\lambda_{1}}^{\prime}(z)}{\beta_{\lambda_{2}}^{\prime}(z)}$

Since scattering is more efficient when the wavelength is of the same order of magnitude as the particle diameter, $\chi^{\prime}$ provides information on the size of the particles in the backscattering layers and, hence, on their nature (cloud droplets, dust or pollution aerosols for instance). It is expected to be lower than 1 for small particles compared to wavelengths. However, in the case of highly absorptive (e.g., smoke) particles and when the aerosol layer is sufficiently thick, the color ratio can become larger than 1 , because the absorption at $532 \mathrm{~nm}$ is significantly larger than at $1064 \mathrm{~nm}$ ). Moreover, $\chi^{\prime}$ cannot be used directly as an aerosol type identification tool, since there is a significant overlap between the distributions of $\chi^{\prime}$ for different aerosol types (Omar et al., 2010). Therefore, it should be used only as a qualitative identification of large/small particles.

For flexibility and computational efficiency, the optical code and the lidar simulator are intentionally designed to process a series of profiles. As our purpose is to compare the model simulations with satellite retrievals (or ground measurements) a preparatory code is used to co-locate spatially $\left( \pm 0.25^{\circ}\right)$ and temporally $( \pm 30 \mathrm{~min})$ and extract the necessary parameters (henceforth as profiles) from the outputs of the model according to the satellite orbit track (or surface site location) selected.

\section{Simulator validation with an academic test case}

In order to validate each step of the calculation, an academic case study is conducted considering simplified atmospheric conditions: only one species and a constant concentration in selected size sections and altitude levels.

The species selected for this demonstration are black carbon (BCAR) and mineral dust (DUST). The main difference
Table 2. Theoretical and calculated AOD at $\lambda=532 \mathrm{~nm}$ per size section.

\begin{tabular}{llllr}
\hline \multirow{2}{*}{ Bin } & Size & \multicolumn{3}{c}{ Aerosol Optical Depth } \\
\cline { 3 - 5 } & Diameter $(\mu \mathrm{m})$ & Theoretical & Simulated & Error $(\%)$ \\
\hline 1 & $0.039-0.078$ & 0.3434 & 0.3467 & 0.9720 \\
2 & $0.078-0.156$ & 0.4682 & 0.4788 & 2.2726 \\
3 & $0.156-0.312$ & 0.5939 & 0.5858 & -1.3714 \\
4 & $0.312-0.625$ & 0.3574 & 0.3485 & -2.4892 \\
5 & $0.625-1.250$ & 0.1617 & 0.1587 & -1.8692 \\
6 & $1.250-2.500$ & 0.0743 & 0.0732 & -1.4374 \\
7 & $2.500-5.000$ & 0.0348 & 0.0345 & -0.8607 \\
8 & $5.000-10.00$ & 0.0166 & 0.0165 & -0.5518 \\
\hline Total & & 2.0502 & 2.0427 & \\
Mean & & & & -0.6669 \\
\hline
\end{tabular}

between these species is that BCAR is strongly absorbing while extinction of the solar radiation from DUST is resulting mainly from scattering.

\subsection{Configuration of the simulator}

For this case study, we distribute a 5 ppbv concentration ( $\sim 17-20 \mu \mathrm{g} \mathrm{m}^{-3}$ depending on altitude) in only one of the size sections of the model at a time. The size distribution for this academic test case is characterised by 8 initial bins (from $40 \mathrm{~nm}$ to $10 \mu \mathrm{m}$, cf. Table 2). The concentration in each initial size section is redistributed to 5 new smaller (equally sized) size sections for higher accuracy in the calculation of the aerosol optical properties. The choice of 40 bins (instead of the initial 8) is made as a function of desired accuracy and computation time (not shown here).

We also consider 18 vertical levels extending from the surface to $200 \mathrm{hPa}$. Vertically, the concentration is located in the lower troposphere, between $\sim 700$ and $\sim 1200 \mathrm{~m}$. This configuration allows us to identify the variability of the calculated parameters as a function of the particle's size.

The refractive indices used for the calculation of their optical properties are shown in Table 3. The scattering and extinction efficiencies calculated for this configuration are shown in Fig. 2. The evolution of these efficiencies as a function of particle size and wavelength will determine the behaviour of the particle optical properties (and, thus, of the AOD) as well as the lidar signal, as discussed below.

First of all, in order to verify the correct computation of the AOD in our code, we calculate independently the theoretical AOD that would result from such conditions and compare them with our results. We achieve an agreement of $99.63 \%$ for the total theoretical AOD. On average, the simulator presents a small negative bias (truncation error). The main source of this bias originates from the interpolation to 40 size sections which affects the computation of $Q_{\text {ext }}$ and $Q_{\text {sca. }}$. For the theoretical case, we also have calculated the total optical depth using finer discretisation of the size sections. 

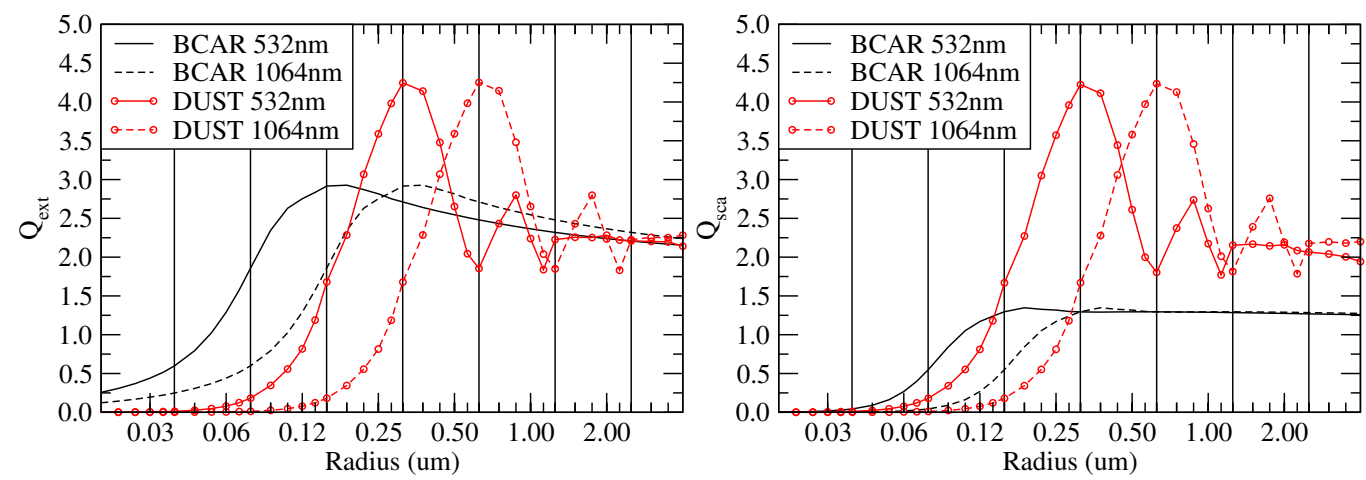

Fig. 2. Black carbon (BCAR) and mineral dust (DUST) extinction $\left(Q_{\text {ext }}\right)$ and scattering $\left(Q_{\text {sca }}\right)$ efficiencies as a function of size (radius) for 2 different wavelengths $(\lambda=532,1064 \mathrm{~nm})$.
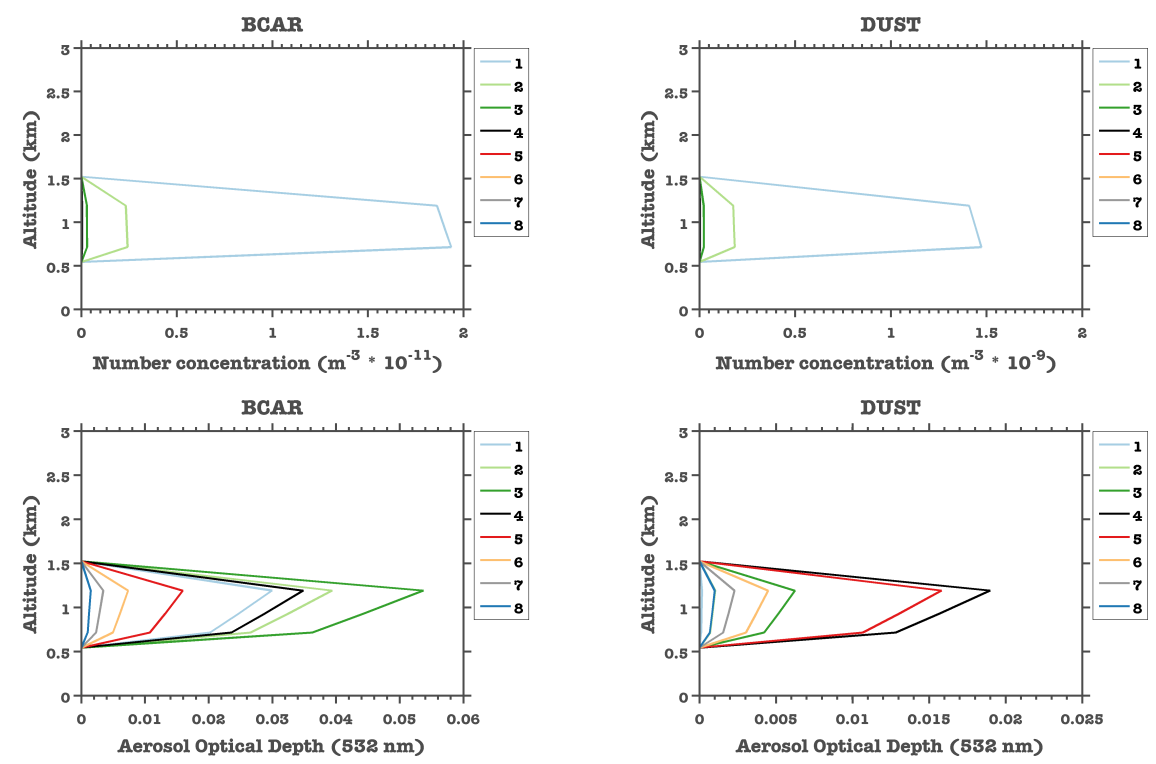

Fig. 3. Profiles of BCAR and DUST concentrations in number and AOD per size section (bin) as a function of altitude and for a wavelength of $532 \mathrm{~nm}$.

The overall bias of this choice was found to be $+7 \%$ for the total AOD (for $40 \times 10^{5}$ bins).

\subsubsection{Aerosol optical depth}

The AOD computed at $532 \mathrm{~nm}$ for the configuration described above and for each vertical level is presented in Fig. 3. As expected, we observe an increase at altitude levels where the concentration was located.

For the BCAR case, the highest value $(\tau=0.053)$ is reached when the aerosol load is distributed in the $0.156-$ $0.312 \mu \mathrm{m}$ bin. AOD is also higher for an increase in the smallest size range $(<0.078 \mu \mathrm{mbin})$ than in the largest one $(5-$ $10 \mu \mathrm{m}$ ), with maximum AOD of $\tau=0.030$ and $\tau=0.001$, respectively. This is explained by the evolution of the number concentration $(N)$ of the particles, which decreases from
$1.86 \times 10^{11} \mathrm{~m}^{-3}$ in the first bin to $0.6 \times 10^{5} \mathrm{~m}^{-3}$ in the 8 th bin, while the mass concentration remains constant. As a result, the maximum AOD is shifted to smaller sizes than that of maximum extinction efficiency $(0.312-0.625 \mu \mathrm{mbin}$ for $532 \mathrm{~nm}$ ), where $N$ is larger.

A similar behaviour is observed for the DUST case. The AOD (for $\lambda=532 \mathrm{~nm}$ ) presents its maximum (0.019) in the $0.312-0.625 \mu \mathrm{m}$ bin as a function of the scattering/extinction efficiency and of the number concentration of particles.

\subsubsection{Attenuated backscatter coefficient}

The $\beta^{\prime}$ profiles calculated for this academic case (for both species) at two different wavelengths $(\lambda=532$ et $1064 \mathrm{~nm})$ are plotted in Fig. 4, showing a behaviour similar to that of the AOD. Its dependence on the aerosol size and, as a result, 

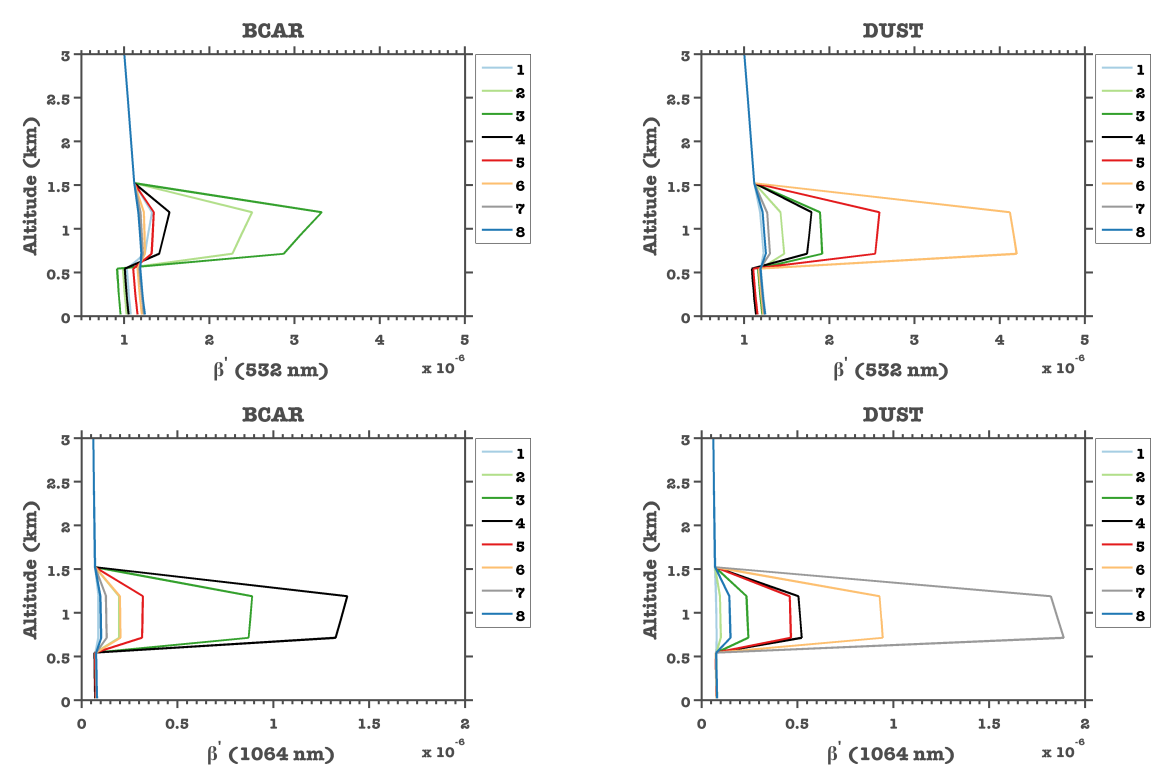

Fig. 4. Profiles of attenuated backscatter $\left(\beta^{\prime}\right)$ for BCAR (left) and DUST (right), per size section (bin) as a function of altitude for $\lambda=532$, $1064 \mathrm{~nm}$.
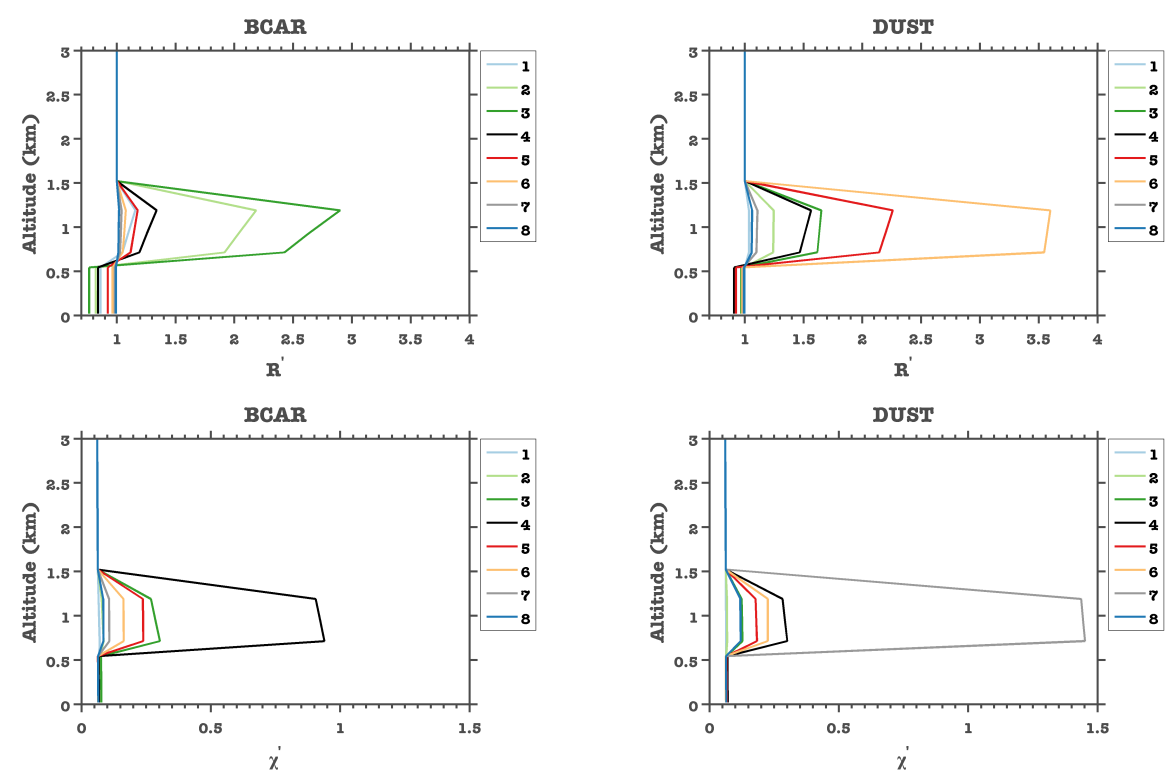

Fig. 5. Profiles of attenuated scattering ratio $\left(R^{\prime}\right)$ and color ratio $\left(\chi^{\prime}\right)$ for BCAR (left) and DUST (right) per size section as a function of altitude.

on $Q_{\text {ext } / \text { sca }}$ and $N$, is highlighted in the BCAR case, for example, by a maximum value $\left(3.32 \times 10^{-6} \mathrm{~m}^{-1} \mathrm{sr}^{-1}\right)$ in the $0.156-0.312 \mu \mathrm{m}$ bin in the $\sim 700-1200 \mathrm{~m}$ altitude layer. Similarly, its maximum $\left(1.38 \times 10^{-6} \mathrm{~m}^{-1} \mathrm{sr}^{-1}\right)$ at $1064 \mathrm{~nm}$ is obtained for the $0.312-0.625 \mu \mathrm{m}$ bin.

Below the simulated plume $(<700 \mathrm{~m}), \beta^{\prime}$ (at $532 \mathrm{~nm}$ ) decreases due to the extinction by the aerosol layer during integration from the TOA to the surface. At $1064 \mathrm{~nm}$ where the extinction is small, $\beta^{\prime}$ values return to the same values as before the aerosol layer. This is less pronounced, but still observed in the DUST case where the extinction is of smaller magnitude (Fig. 3). 


\subsubsection{Scattering and color ratios}

The $R^{\prime}(z)$ and $\chi^{\prime}(z)$ profiles associated to the $\beta^{\prime}$ presented above (Fig. 4) is shown in the Fig. 5 (top). Their variability is directly related to that of $\beta^{\prime}$ for both species.

For really small particles $(R / \lambda<0.1)$ the $\beta_{1064}^{\prime} / \beta_{532}^{\prime}$ ratio is almost constant. In this case, extinction controls the evolution of $\chi^{\prime}$ with altitude Fig. 5 (bottom). At the 0.312$0.625 \mu \mathrm{m}$ bin where extinction at $1064 \mathrm{~nm}$ is maximum and the backscattering coefficient $\beta$ becomes higher (Fig. 2) than the one at $532 \mathrm{~nm}$, we obtain $\beta_{1064}^{\prime}>\beta_{532}^{\prime}$. Consequently, $\chi^{\prime}$ reaches its highest value. When the two $\beta$ coefficients begin to converge, extinction is decreasing which results in a decrease of $\chi^{\prime}$.

\subsubsection{Uncertainties in lidar parameters}

The calculation of the aerosol optical properties in OPTSIM is subject to two main sources of uncertainties: the limitation to single scattering and the assumption that all particles are spherical.

Multiple scattering becomes critical in the case of dense aerosol layers (AOD $\geq 1$ ) as discussed in Liu et al. (2011). In the same study, it was found that the impact of multiple scattering is small when the dust extinction is smaller than $1 \mathrm{~km}^{-1}$, while it can be large when the extinction is equal to $2 \mathrm{~km}^{-1}$ or larger. Wandinger et al. (2010) showed, by comparing CALIPSO and ground-based dust observations on a case study, that neglecting this effect can result in an reduction of the extinction coefficient by $20 \%$ to $30 \%$ (for effective radii of 3 and $6 \mu \mathrm{m}$ and for the CALIOP geometry). According to CALIPSO quality assessment report, in the case of dense aerosol layers, the uncertainty introduced due to multiple scattering is estimated on average at the 10-20\% level. In order to quantify the bias in our simulations due to multiple scattering, we have conducted a sensitivity study using different $\eta^{\prime}$ values (Fig. 6). According to the estimations given above and Winker et al. (2003), we consider that dust $\eta^{\prime}$ values vary between 0.6 and 0.9 as a function of the layer's thickness. For aerosol layers deeper than $500 \mathrm{~m}, \eta^{\prime}$ is greater than 0.85 and so the multiple scattering has only a small effect (Winker et al., 2003). The greatest divergence $(2.08 \%)$ from the reference case value $\left(\eta^{\prime}=1\right)$ is obtained for $\eta^{\prime}=0.6$ which is considered an extreme value. In general, the differences are higher in the 4th size section, for which extinction is highest (Sect. 3.1.1) as multiple scattering mainly affects extinction.

The behaviour of $\chi^{\prime}$ is more complicated. We notice a general slight decrease (maximum $-1.7 \%$ for $\eta^{\prime}=0.6$ ) which is always more pronounced in the 4 th size section. However, there is also a marginal increase in the 6th size section. This can be explained by the difference in extinction between 532 and $1064 \mathrm{~nm}$ (cf Sect. 3.1.2). More specifically, in this size section, $\beta_{1064}^{\prime}$ is increasing slightly more $(0.86 \%)$ than $\beta_{532}^{\prime}$ $(0.48 \%)$ which results in a higher $\chi^{\prime}$.
The spherical shape approximation is more critical, especially for mineral dust. The non-spherical shape of dust particles is known to reduce the backscattering efficiency and increase the extinction-to-backscatter ratio (lidar ratio) compared to surface-equivalent spheres (e.g. Mishchenko et al., 1997; Mattis et al., 2002, and references therein), but with lower influence on the extinction coefficient (e.g. Müller et al., 2003). Indeed, the shape of aerosols has strong impact on the phase function, especially in the backward direction $\left(180^{\circ}\right)$ where it is lower for non-spherical particles (e.g. Mishchenko et al., 1997). Müller et al. (2003) showed that errors in the phase functions may reach $50 \%$ if the wrong particle shape is considered. Gasteiger et al. (2011) estimate that spherical dust particles result in a lidar ratio 55-70\% lower than other spheroid shapes.

In order to estimate the variability of the simulated lidar parameters used here $\left(R^{\prime}\right.$ and $\left.\chi^{\prime}\right)$, we have conducted a sensitivity test with different values of the backscattering phase function values $\left(P_{\pi}\right)$. Figure 7 shows that both $R^{\prime}(z)$ and $\chi^{\prime}$ are decreasing along with $P_{\pi}$. For example, a $50 \%$ decrease in $P_{\pi}$ results in a $36.16 \%$ decrease for $R^{\prime}$ (in the 6th size section) and $45.31 \%$ for $\chi^{\prime}$ (in the 7 th size section). However, the exact uncertainty introduced because of the spherical shape approximation remains difficult to quantify since additional uncertainties are introduced by the variability in the chemical compositions, particle size distributions, and shape (e.g., aspect ratio) of dust particles. The use of randomly oriented spheroids is known (e.g. Dubovik et al., 2002b) to achieve higher accuracy. In order to better quantify the differences between spherical and non-spherical particles, a T-matrix calculation has to be used. As the development of OPTSIM is on going, the issue of non-sphericity will be addressed in the future versions.

\section{Observations}

Our simulator allows the calculation of a series of optical properties that can be directly compared to observations. The optical thickness observed by passive remote sensors are widely used for the validation of aerosol modelling by CTMs. In the analysis presented in Sect. 6, we will present comparisons to AOD measurements as a first step of the evaluation, before detailing the additional information provided by lidar observations. In this section, the observations that have been used in the illustration are briefly described.

\subsection{Aerosol optical thickness from passive remote sensing}

The AERONET sun photometer network provides groundbased measurements of the AOD at several wavelengths and key aerosol properties (Angström exponent, size distributions, single scattering albedo, etc.) that have been used as a primary validation tool in the modelling community. Here, 

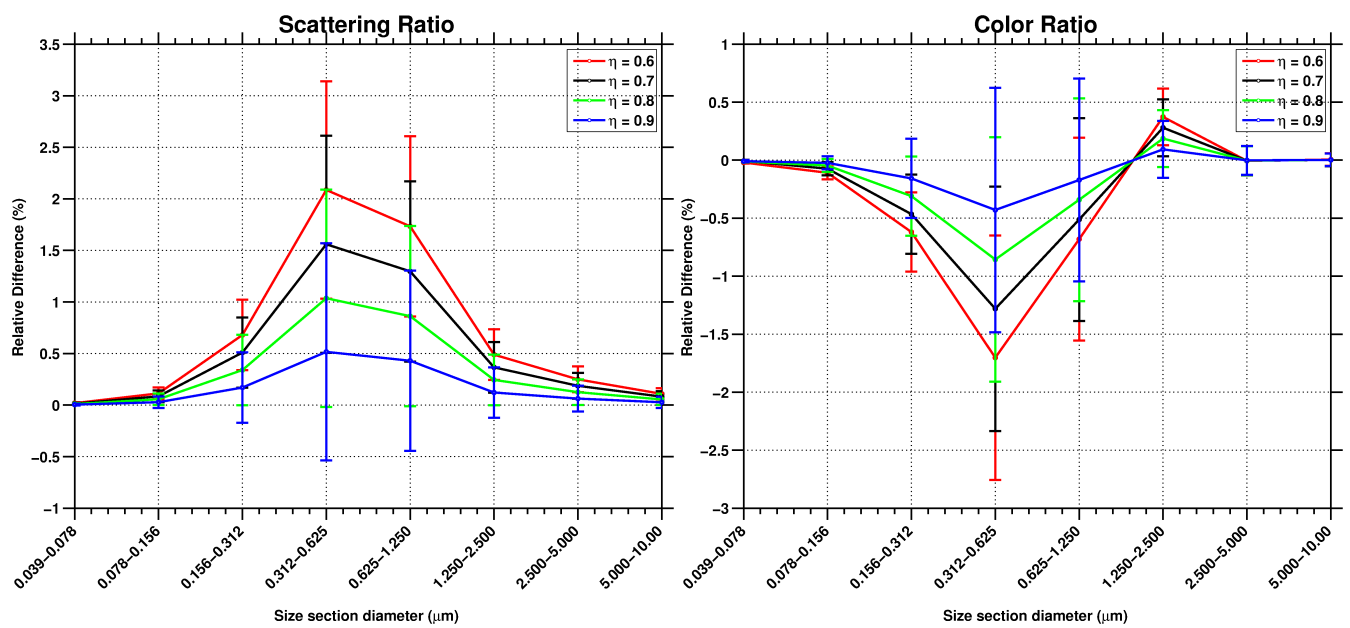

Fig. 6. Differences in the simulated attenuated scattering ratio (left) and color ratio (right) per size section as a function of the backscattering phase function value.
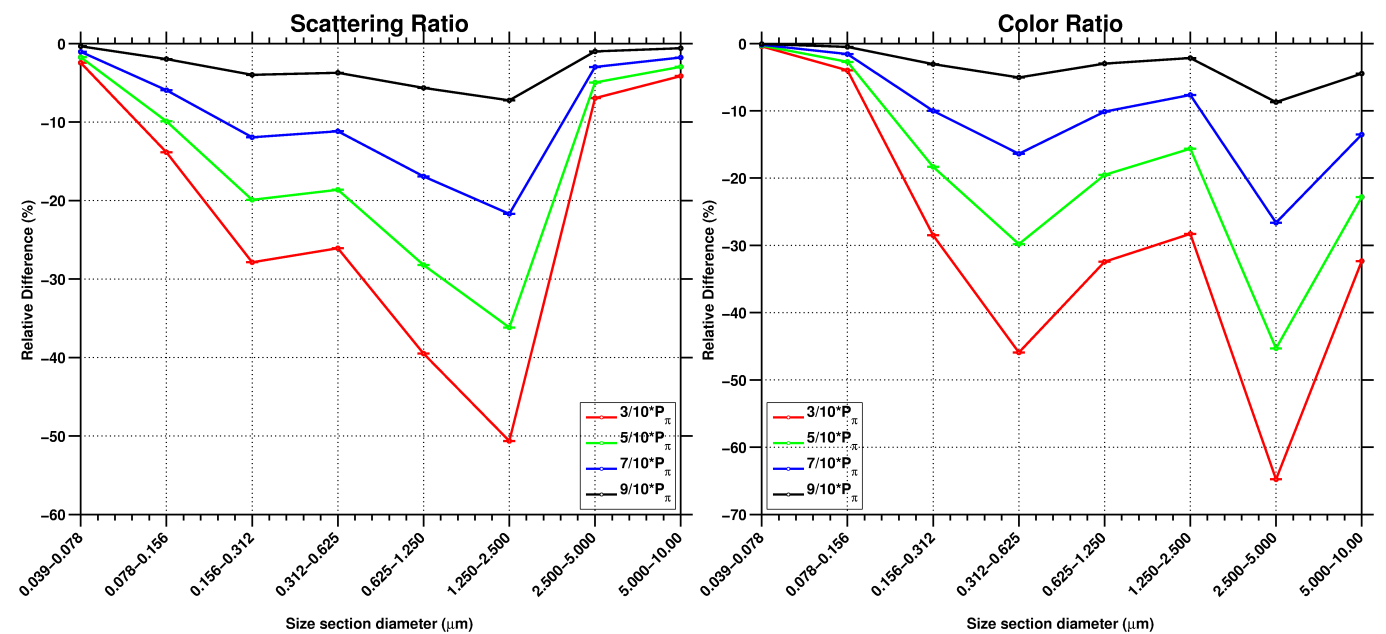

Fig. 7. Differences in the simulated attenuated scattering ratio (left) and color ratio (right) per size section as a function of the multiple scattering parameter $\eta^{\prime}$.

we use the level 2.0 cloud screened and quality-assured retrievals of the aerosol optical depth at $500 \mathrm{~nm}$ (with a fine and coarse mode separation) and Angström's exponent (Holben et al., 1998; Dubovik and et al., 2000).

As a complement, the satellite retrievals of AOD from passive remote sensors are particularly well suited for the analysis of the temporal and horizontal distributions of aerosols since they provide measurements with global coverage every one or two days. Here, we use the MODIS/Aqua collection 5.1 level 2 data. The retrieved MODIS AOD $(\tau)$ is estimated to be accurate to $\pm 0.05( \pm 0.15 \cdot \tau)$ over the land and $\pm 0.03( \pm 0.05 \cdot \tau)$ over the ocean (Levy et al., 2010) and is known to correlate well with the AERONET sunphotometer measurements. (Bréon et al., 2011) report a correlation of $0.829 / 0.904$ with a RMSD of $0.118 / 0.125$ for the total
$\mathrm{AOD}$ at $500 \mathrm{~nm}$ over ocean/land and a slight positive bias $(+0.02)$. Aerosol products are provided at a spatial resolution of $10 \mathrm{~km} \times 10 \mathrm{~km}(20 \times 20$ pixels of $500 \mathrm{~m} \times 500 \mathrm{~m}$ resolution).

\subsection{Lidar vertical profiles with CALIOP}

The simulator can be used for the comparison of model outputs to surface or space-based lidar observations. Since the application examples are focused on satellite observations from the CALIPSO mission, it is here briefly introduced. 


\subsubsection{CALIOP data characteristics}

The CALIOP lidar is operating since April 2006 on board the sun-synchronous satellite CALIPSO as a part of the Atrain constellation. It measures vertical backscatter profiles from aerosols and clouds at $532 \mathrm{~nm}$ and $1064 \mathrm{~nm}$ in the troposphere and lower stratosphere (Winker et al., 2009) with a nadir-viewing geometry (14-days revisit time). The L1 processing consists of three-dimensional geo-location followed by calibration (Powell and al., 2009).

The resulting Level 1B data (with a horizontal resolution of $333 \mathrm{~m}$ ) contain Molecular Density (MD) profiles, profiles of total attenuated backscatter coefficient $\left(\beta^{\prime}\right)$ at the two wavelengths and profiles of cross polarised attenuated backscatter $\left(\beta_{\text {perp }}^{\prime}\right)$ at $532 \mathrm{~nm}$. The vertical resolution of the $532 \mathrm{~nm}$ channel is altitude-dependent from $30 \mathrm{~m}$ (up to $8.2 \mathrm{~km}$ ) to $1000 \mathrm{~m} \times 60 \mathrm{~m}(8.2-20.2 \mathrm{~km}$ ), while it is $1000 \mathrm{~m} \times 60 \mathrm{~m}$ up to $20.2 \mathrm{~km}$ for the $1064 \mathrm{~nm}$ channel, with a total of 583 vertical levels distributed from the surface up to $40 \mathrm{~km}$. The molecular density profile is derived from Goddard Modelling and Assimilation Office (GMAO) atmospheric profiles (Bey et al., 2001) for 33 vertical levels between the surface and $40 \mathrm{~km}$.

Uncertainty sources on L1B data include possible calibration biases, lidar scattering signal noise (shot noise) and background noise (e.g. Winker et al., 2009; Powell and al., 2009). As the daytime measurements contain higher noise levels than night time measurements due to solar background signals (e.g. Hunt et al., 2009), we will limit our analyses to night-time observations only.

\subsubsection{Computation of the observed attenuated scattering ratio $\left(R_{\text {obs }}^{\prime}\right)$}

For this purpose, we compute the scattering ratio $\left(R^{\prime}\right)$ following the same method as in (Chepfer et al., 2010). The basic methodology described in their Sect. 2.1 is reminded in the following.

First, the measured attenuated backscattered profile $\left(\beta^{\prime}\right.$ over 583 vertical levels) and the MD profile (33 vertical levels) are each independently averaged or interpolated onto 80 -level vertical levels ( $240 \mathrm{~m}$ thick), leading to the $\beta_{\text {vert }}^{\prime}$ and $\mathrm{MD}_{\text {vert }}$ profiles. This averaging significantly increases the $\beta^{\prime}$ signal-to-noise ratio. The initial horizontal resolution $(333 \mathrm{~m})$ is kept in order to screen the small boundary layer clouds (next section).

To convert the MD profile into molecular profile $\beta_{\mathrm{mol}}^{\prime}$, the $\beta_{\text {vert }}^{\prime}$ and $\mathrm{MD}_{\text {vert }}$ profiles are analysed and averaged in cloudfree portions of the stratosphere $(22<z<25 \mathrm{~km}$ for night time data). At these altitudes, $\beta_{\mathrm{vert}}^{\prime}$ and $\mathrm{MD}_{\text {vert }}$ profiles are each averaged horizontally over \pm 33 profiles $( \pm 10 \mathrm{~km})$ on both sides of a given profile.

The ratio between these two values $\left(<\beta_{\text {vert }}^{\prime}>/<\right.$ $\mathrm{MD}_{\text {vert }}>$ is then used to scale the MD vert profile into an attenuated backscatter molecular signal profile $\left(\beta_{\text {vert,mol }}^{\prime}\right)$. The latter is the $\beta_{\text {mol }}^{\prime}$ profile that would be measured in the absence of clouds and aerosols in the atmosphere. The measured lidar attenuated scattering ratio profile $\left(R_{\mathrm{obs}}^{\prime}\right)$ is then computed by dividing the $\beta_{\text {vert }}^{\prime}$ profile by the $\beta_{\text {vertmol }}^{\prime}$ profile. Its horizontal resolution is $330 \mathrm{~m}$ and the vertical resolution is $240 \mathrm{~m}$.

Pixels located below and at the surface level are rejected by using the "altitude-elevation" flag from level 1 CALIOP data.

\subsubsection{Cloud screening in the observations}

Clouds dominate the received signal and as a result the contribution of aerosols is undermined in cloudy situations. Since we are primarily interested in aerosols, a cloud filter will be used to eliminate cloud-contaminated profiles. Boundary layer clouds can have a small horizontal extension, even lower than $1 \mathrm{~km}$ (e.g. Medeiros et al., 2010; Koren et al., 2008; Konsta et al., 2012). For this reason, we need to use high horizontal resolution $R^{\prime}$ profiles for cloud detection.

The threshold on $R^{\prime}$ used to detect clouds (or aerosols) is altitude and resolution dependent, due to the nature of the noise imposed on the lidar backscatter signal. It presents lower values in regions of (relatively) high clear air SNR, and higher threshold values in low clear air SNR (e.g., high altitude) regions. Here the lidar profile is considered to be cloudcontaminated when $R^{\prime} \geq 7.5$ is detected in a 3-profiles running average ( $1 \mathrm{~km}$, used to reduce noise level). This threshold value $\left(R^{\prime}=7.5\right)$ has been adjusted based on sensitivity studies (not shown) using lidar profiles at the resolution used here (240 m vertical and $330 \mathrm{~m}$ horizontal, as in Chepfer et al., 2010).

For optically thick clouds (typically with optical depth larger than 3), the lidar signal is fully attenuated below the cloud, and the pixels located below cloud are filtered out. For high altitude clouds with moderate optical depth $(<3$, typically cirrus clouds), the lidar signal is attenuated in the observations ( $R^{\prime}$ can be lower than 1) below the cloud, but above the top model level depending on the model's configuration. This attenuation will then not be accounted for in the model, and an artificial bias may occur between modelled and observed $R^{\prime}$. To avoid this problem, the observed $R^{\prime}$ is forced to 1 at the top model boundary. The required scaling factor is applied to the whole profile. Otherwise, only the peak at the cloud location is removed.

Finally, the cloud-free data are averaged at the model's horizontal and vertical resolutions for direct comparison to the simulated $R^{\prime}$ profiles.

\subsubsection{Aerosol detection limits}

The nighttime aerosol detection threshold used here is $R^{\prime}=$ 1.2 for the $532 \mathrm{~nm}$ channel (Chepfer et al., 2012). Using this threshold value (which is considered to be an upper limit, since we are averaging profiles), a theoretical calculation of 
Table 3. List of species accounted for by the CHIMERE optical module, wavelength-dependent complex refractive index and density of each aerosol species. All refractive indices and density values are taken from the ADIENT/APPRAISE technical report (http://www.met.reading. ac.uk/adient/).

\begin{tabular}{llll}
\hline Species & Model & \multicolumn{2}{c}{ Refractive index } \\
\cline { 3 - 4 } & Species & $532 \mathrm{~nm}$ & $1064 \mathrm{~nm}$ \\
\hline Organic carbon & OCAR & $1.63-2.32 \times 10^{-2} i$ & $1.63-7.0 \times 10^{-4} i$ \\
Black carbon & BCAR & $1.85-7.10 \times 10^{-1} i$ & $1.85-7.10 \times 10^{-1} i$ \\
Mineral dust & DUST & $1.53-1.20 \times 10^{-3} i$ & $1.53-7.74 \times 10^{-4} i$ \\
Secondary organic aerosols & SOA & $1.56-3.0 \times 10^{-3} i$ & $1.56-3.0 \times 10^{-3} i$ \\
Equivalent sulfate & H2SO4 & $1.44-1.0 \times 10^{-8} i$ & $1.42-1.64 \times 10^{-6} i$ \\
Equivalent nitrate & HNO3 & $1.61-0 i$ & $1.59-1.8 \times 10^{-5} i$ \\
Equivalent ammonium & NH3 & $1.53-1.0 \times 10^{-7} i$ & $1.51-2.35 \times 10^{-6} i$ \\
Sea salt & SALT & $1.50-1.20 \times 10^{-8} i$ & $1.47-1.97 \times 10^{-4} i$ \\
Water $^{\star}$ & H2O & $1.333-1.9 \times 10^{-9} i$ & $1.326-4.18 \times 10^{-6} i$ \\
\hline
\end{tabular}

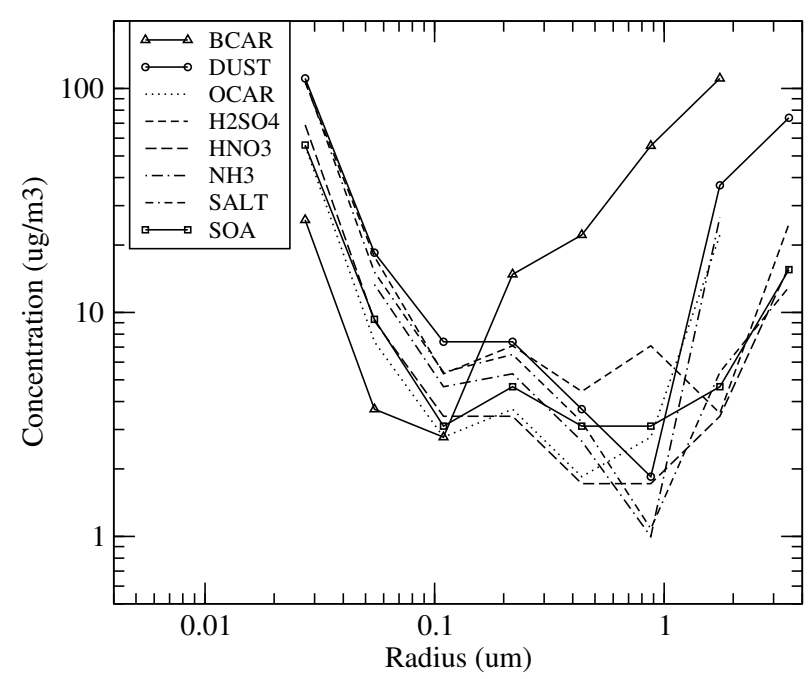

Fig. 8. Theoretical minimum detectable concentration $\left(\mu \mathrm{g} \mathrm{m}^{-3}\right)$ per size section corresponding to $R^{\prime} \geq 1.2$ (CALIOP night-time threshold) for each of the aerosol species considered by the model. Concentrations are considered at altitudes between $\sim 700$ and $\sim$ $1200 \mathrm{~m}$.

the minimum detectable concentration per species (one at a time) and size section was conducted. The corresponding results are shown in Fig. 8. We notice that a crucial parameter in determining these values, is the size and number concentration of the particles, as explained in Sect. 3.1.1.

The minimum detectable concentration for each species using a typical size distribution for urban, suburban and rural areas, is also calculated. In general, for concentrations in the lower troposphere (cf. Sect. 3.1) the median for the minimum detectable concentration for all species considered is between $\sim 2.4$ and $\sim 5.5 \mu \mathrm{g} \mathrm{m}^{-3}$ (BC 4.7, OC 3.8, $\mathrm{H}_{2} \mathrm{SO}_{4} 5.5$, $\mathrm{HNO}_{3} 2.4, \mathrm{NH}_{3} 3.4$, SALT 3.3 and SOA $3.2 \mu \mathrm{g} \mathrm{m}^{-3}$ ). The highest concentration value is observed for mineral dust (me- dian $11.3 \mu \mathrm{g} \mathrm{m}^{-3}$ ). Comparing with orders of magnitudes observed in different locations in Europe (Putaud et al., 2010), these limits of detection will be generally exceeded in polluted conditions (urban), but they are below or close to the limits in rural and suburban sites.

\section{Meteorology and chemistry transport modelling}

For this study, we use the offline chemistry transport model CHIMERE (version 2011b), coupled with the mesoscale model Weather Research and Forecasting (WRF) in its 3.2.1 version and in its non-hydrostatic configuration. We use the same model configuration as in studies such as Rouil et al. (2009) and Bessagnet et al. (2010). Both meteorology and chemical concentrations results are obtained with an hourly frequency. A detailed documentation of the physical and chemical parameterisations used in CHIMERE is available online http://www.lmd.polytechnique.fr/chimere/. Regarding particulate matter, an extensive evaluation of the model at a regional scale can be found in (Vautard et al., 2007) and (Bessagnet et al., 2008). The aerosols species considered by the model are sulphates, nitrates, ammonium, organic aerosols and sea-salt. For a detailed description of the aerosol module in CHIMERE, the reader is referred to (Bessagnet et al., 2004).

The surface emissions account for anthropogenic, biogenic, mineral dust and fires sources. The anthropogenic emissions preprocessing is described in (Menut et al., 2012). The MEGAN model (Guenther et al., 2006) is used for the biogenic emissions while the mineral dust emissions are described in (Menut, 2008).

Two nested domains are defined in order to model the synoptic scale over a large African-Euro-Mediterranean domain and the local scale with an included Euro-Mediterranean domain. In this study, the results are presented only for the smallest domain (from $4^{\circ} \mathrm{W}$ to $34^{\circ} \mathrm{E}$ and from $24.7^{\circ} \mathrm{N}$ to 

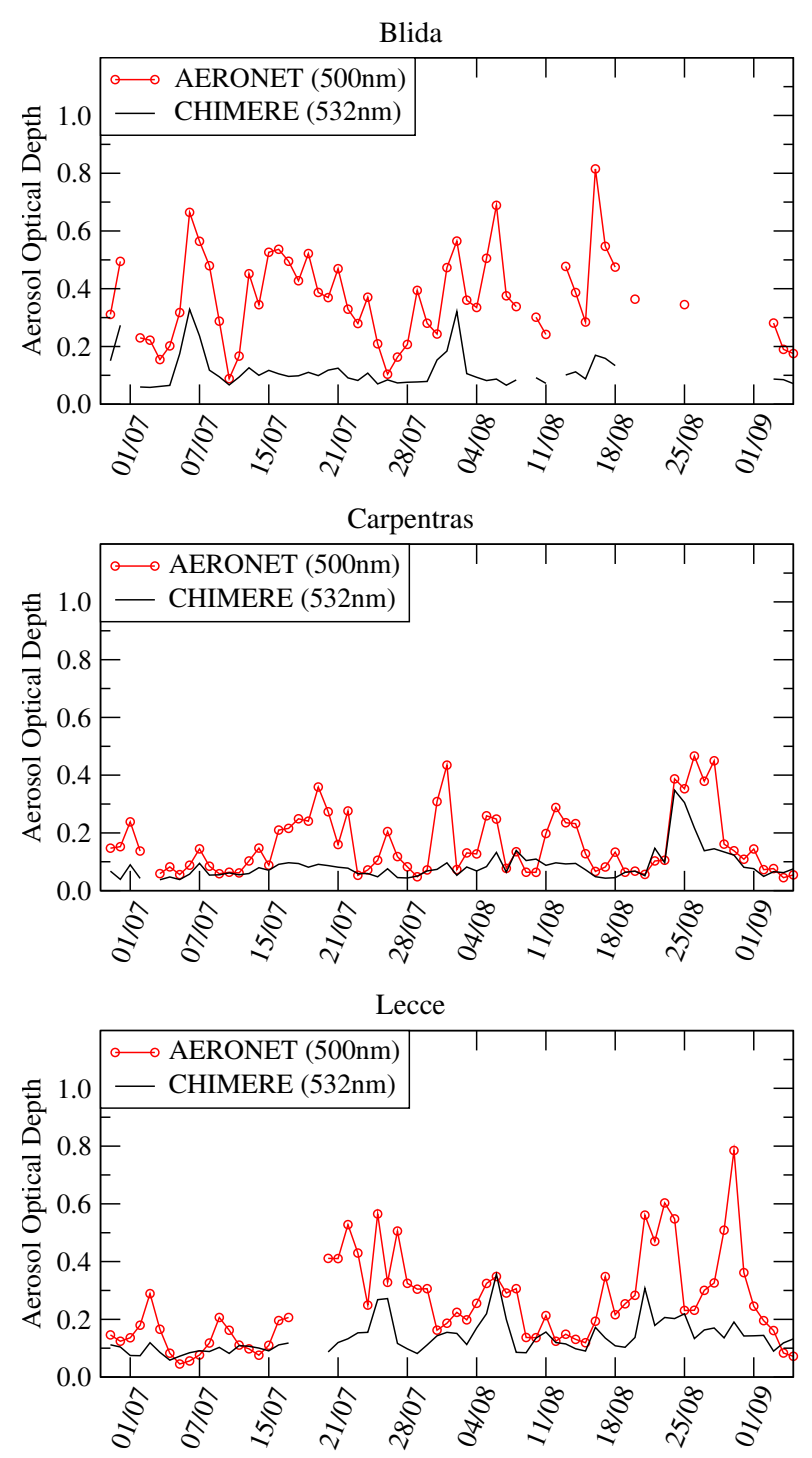

Fig. 9. Temporal evolution of the daily mean AOD $(500 \mathrm{~nm})$ by AERONET (red line) and the corresponding CHIMERE AOD (at $532 \mathrm{~nm}$, black line) at three AERONET sites (Blida, Carpentras, Lecce).

$45.4^{\circ} \mathrm{N}$ ), with a horizontal resolution of $20 \mathrm{~km}$. The vertical grid contains 18 uneven layers starting from the surface pressure level and reaching $200 \mathrm{hPa}$. Finally, this simulation covers the time interval 29th June - 6th September 2007.

\section{Analysis of dust events in the Euro-Mediterranean area during the summer 2007}

Mineral dust is well known to contribute to atmospheric pollution in urban areas in addition to local anthropogenic pollutants over the Euro-Mediterranean region (e.g., Bessagnet et al., 2008; Querol et al., 2009). Transported mainly from the Sahara desert (Laurent et al., 2008), it often results in an ex-

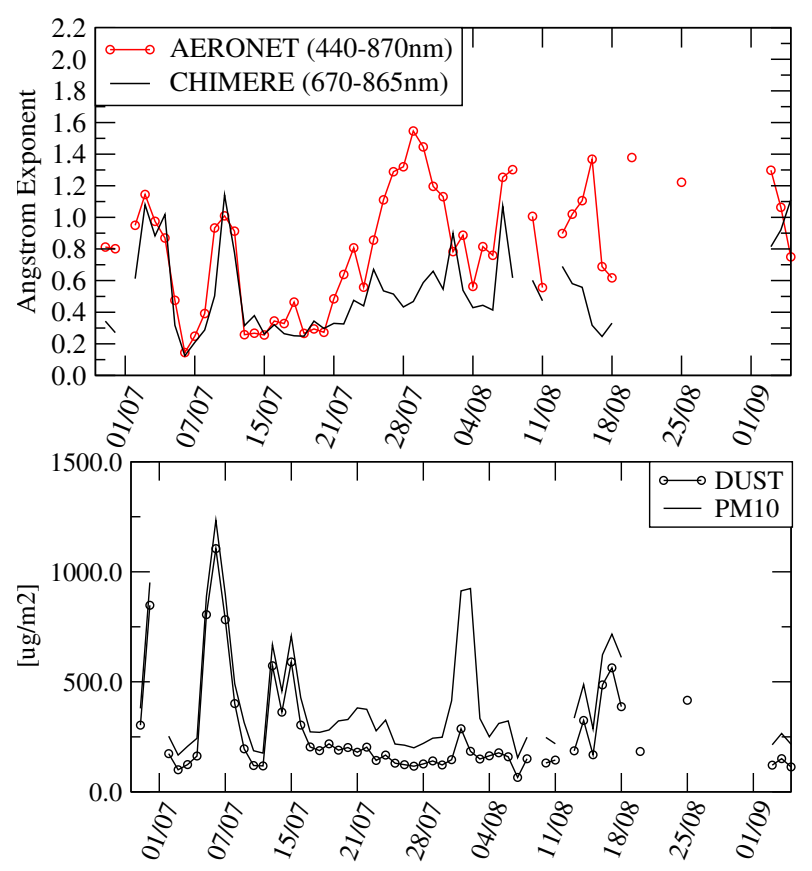

Fig. 10. Temporal evolution of the daily mean and Angström exponent $(440-870 \mathrm{~nm})$ for the AERONET station in Blida $\left(2.88^{\circ} \mathrm{E}\right.$, $36.5^{\circ} \mathrm{N}$ ) between 29 June and 6 September 2007 and the corresponding CHIMERE Angström exponent (at 670-865 nm, red line). The daily mean (for the same hours as the measurements) dust and $\mathrm{PM}_{10}$ concentration is shown in the bottom figure.

ceedance of the air quality thresholds in the most concerned countries like Spain (e.g. Escudero et al., 2007), Italy (e.g. Gobbi et al., 2007) or Greece (e.g. Kaskaoutis et al., 2008).

\subsection{Comparisons to AERONET and MODIS AOD}

The dust episodes analysed took place near the AERONET station in Blida (Algeria). The model shows large increase in dust load for the two events, corresponding to transport from emissions in the Algerian part of the Sahara desert.

The general situation during the summer 2007 was first analysed using comparisons between the CHIMERE simulation and retrievals from the AERONET network for the total AOD at $500 \mathrm{~nm}$. Figure 9 shows the results at several observation sites around the Mediterranean Basin. The agreement for background AOD levels is satisfying and most events are captured in the Carpentras and Lecce sites (correlations of $63 \%$ and $56 \%$, respectively). However, the magnitude of the observed AOD peaks is generally underestimated. These scores are in consistency with current air quality models performances (e.g. Stern et al., 2008). The highest AOD values are observed at the Blida site (North of Algeria), which is particularly well-suited for the analysis of dust impact in the Euro-Mediterranean region since it is located within the Northern Saharan domain. The correlation 
AOD MODIS, 7-9 July 2007

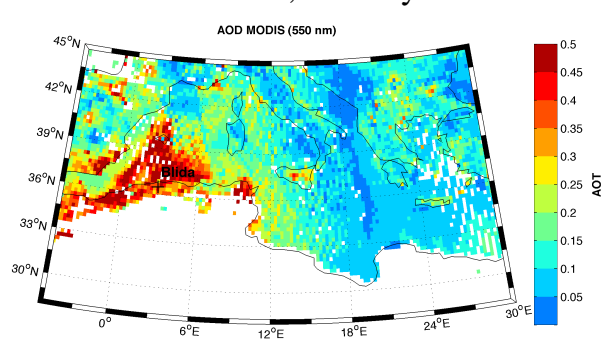

AOD MODIS, 13-15 July 2007

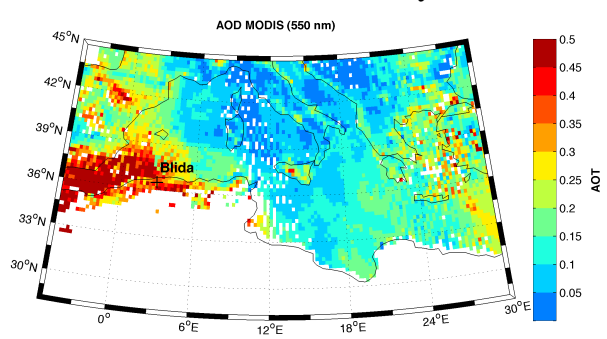

AOD CHIMERE, 7-9 July 2007

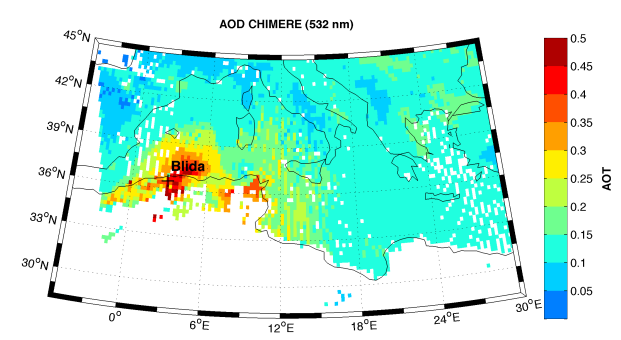

AOD CHIMERE, 13-15 July 2007

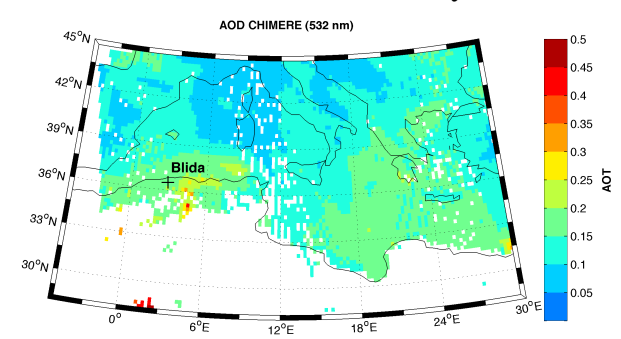

Fig. 11. Maps of mean AOD by MODIS (550 nm) and CHIMERE (532 nm) during the 7-9 and 13-15 July 2007 dust events. MODIS data are re-gridded to the resolution of the model.

between model and observations is $58 \%$, the bias (modelobservation) is -0.25 with a RSME 0.28 for the AOD $(500 \mathrm{~nm})$. The Angström exponent at $440-870 \mathrm{~nm}$ and the contribution of dust to the total aerosol load in the model simulation is shown in Fig. 10. Several major dust events were detected, with large AOD and low Angström exponent values (desert dust aerosols are characterised by low $\alpha$ values, ranging generally from $\sim 1.2$ down to $\sim-0.1$ (e.g. Dubovik et al., 2002a). The very good agreement between the model and AERONET for the low values of the Angström exponent suggests that the average size of aerosols is correctly simulated for the dust events, but the peak AOD values in the observations are generally underestimated in the model.

The MODIS AOD and corresponding CHIMERE AOD are shown in Fig. 11. According to the observations, both events were characterised by intense dust emissions, covering the west-northern part of Africa and resulting in AOD (at $550 \mathrm{~nm}$ ) values up to 0.93 while a large plume was observed moving northeastward over the Mediterranean Basin. The comparisons for the 7-9 July 2007 time period show that the localisation and the simulated transport of the plume is consistent with the observations. However, its intensity and extent are underestimated, indicating a negative bias in the emissions and/or a transport error. Regarding the second event, a small, very local dust plume is simulated while its intensity and extent are missed.

We have chosen to analyse more specifically two events, for which CALIOP measurements are also available (see following section): 7-9 July 2007 (well captured in the sim- ulation) and 13-15 July 2007 (underestimated). The model shows large increase in dust load for the two events, corresponding to transport from emissions in the Algerian part of the Sahara desert. However, it is significantly lower for the 13-15 July 2007 event than for the 7-9 July 2007 event. The transport pathways for the 2 nd event show that the bulk of the dust plume is located to the east of the AERONET station in Blida. The strong underestimation may, thus, result from underestimating emissions as well as from an error in estimated transport.

\subsection{Comparisons to CALIOP observations}

For each of the events presented in the previous section, the corresponding CALIPSO orbit is plotted in Fig. 12 along with the corresponding AOD (for $\lambda=532 \mathrm{~nm}$ ) simulated by OPTSIM.

Comparisons between the CHIMERE simulations and the L2 observations are first presented, as it is the approach classically used by modellers. We then discuss in more detail what can be learned from the comparisons to L1 observations, also allowed by OPTSIM.

\subsubsection{Comparisons to CALIOP extinction and backscatter coefficients}

The observed $\mathrm{L} 2$ extinction and backscatter coefficients, and the corresponding CHIMERE simulations for the 7-9 July event are shown in Fig. 13. An aerosol layer can be clearly seen in both figures across the orbit portion. The maximum 

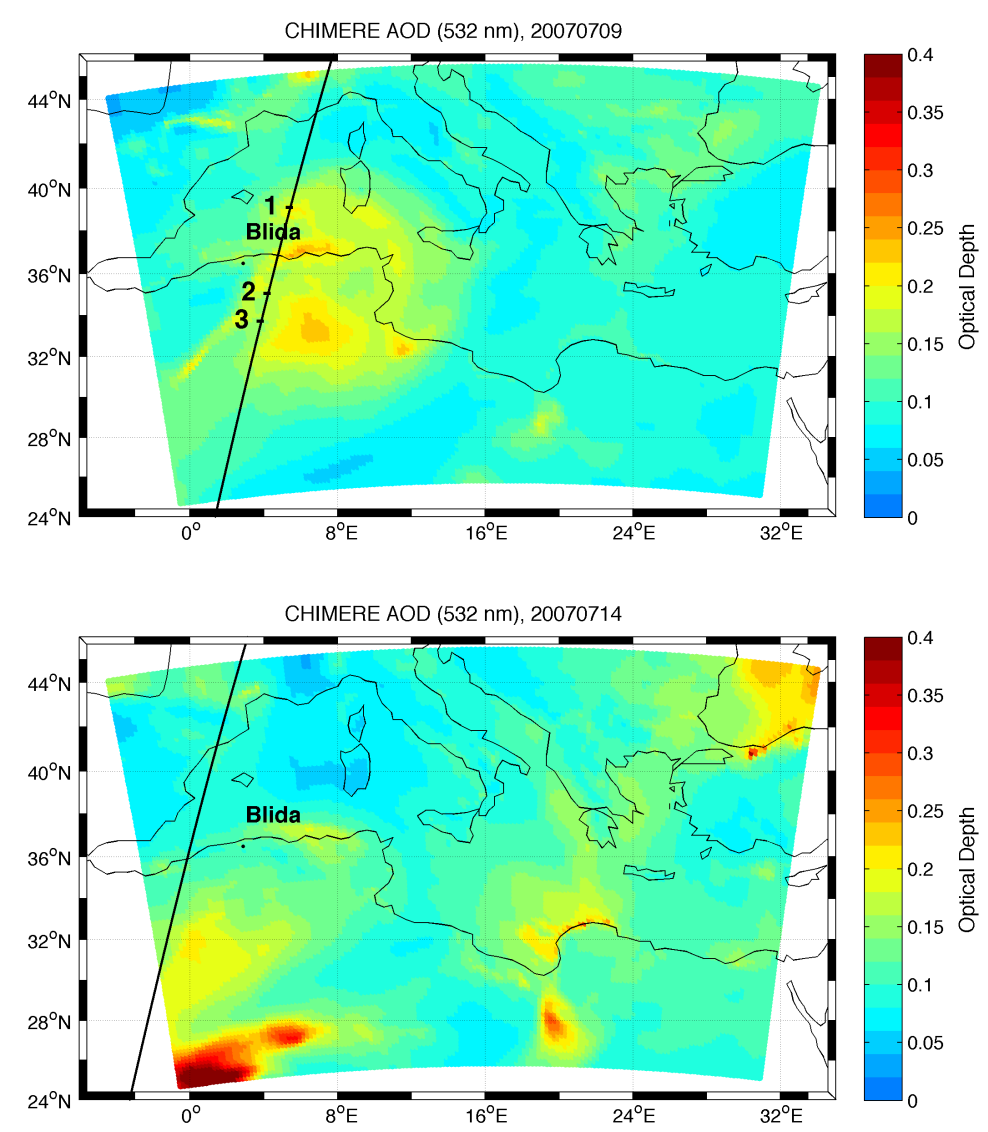

Fig. 12. Aerosol Optical Depth modelled with CHIMERE for $\lambda=532 \mathrm{~nm}$ for the 9 and 14 July 2007 at the same hour as the CALIPSO overpass time.

for both coefficients is located above the continent around $35^{\circ} \mathrm{N}$ near the Blida station, while the plume is extending towards the sea. Vertically it is located between $\sim 1.5$ to $\sim 4.5 \mathrm{~km}$. In CHIMERE, an aerosol layer is simulated in the same area, but both coefficients are strongly underestimated. The extinction coefficient underestimation is notably larger. This could be explained by the aerosol type identification in the CALIPSO classification algorithm. Indeed a large fraction of the observed dust layer is identified as polluted dust. On the other hand, CHIMERE is simulating mainly dust in this area. The exact contribution of dust to the simulated lidar signal is discussed in the following section.

\subsubsection{Comparisons to CALIOP scattering and color ratios}

The corresponding L1 parameters $\left(R^{\prime}\right.$ and $\left.\chi^{\prime}\right)$ are presented in Figs. 14 and 15. In consistency with the L2 products, the CALIOP $R^{\prime}$ observations show an aerosol layer around $35^{\circ} \mathrm{N}$ near the Blida station. Vertically it is extending from $\sim 3$ to $\sim 4.5 \mathrm{~km}(\sim 2.5 \mathrm{~km}$ large $)$, and above the sea in the northeastward direction at $\sim 1$ to $3 \mathrm{~km}$ altitude. For this event, the general structure of the plume is well reproduced in the
CHIMERE simulation. However, its vertical extent is overestimated.

We also notice that the thickness of the aerosol layer appears diminished in comparison with the L2 observations. This can be explained by the impact of extinction to $\beta^{\prime}$, which results in a smaller attenuated scattering ratio. In agreement with the observations, the same behaviour is observed in the simulated $R^{\prime}$.

Three individual $R^{\prime}$ profiles are presented in Fig. 17: one corresponding to the maximum observed $R^{\prime}\left(35.19^{\circ} \mathrm{N}\right)$; the second located over the sea $\left(39.23^{\circ} \mathrm{N}\right)$; the third $\left(33.91^{\circ} \mathrm{N}\right)$ closer to the area of the dust emissions. They correspond to points 1, 2, 3 in Fig. 12. According to CHIMERE, the dominant species in both cases is dust $(97.3 \%$ and $93.5 \%)$ although in the second profile (over the sea) we see a higher contribution of sea salt above the surface level $(3.5 \%)$. For the entire portion of the orbit within the simulated domain, the mean altitude of the maximum simulated $R^{\prime}$ is $4.51 \mathrm{~km}$ against $2.93 \mathrm{~km}$ for CALIPSO, with a RSME of $2.53 \mathrm{~km}$ and a correlation 0.45 .

The model $R^{\prime}$ value is underestimated near the observed peak and overestimated over the Mediterranean sea. This 

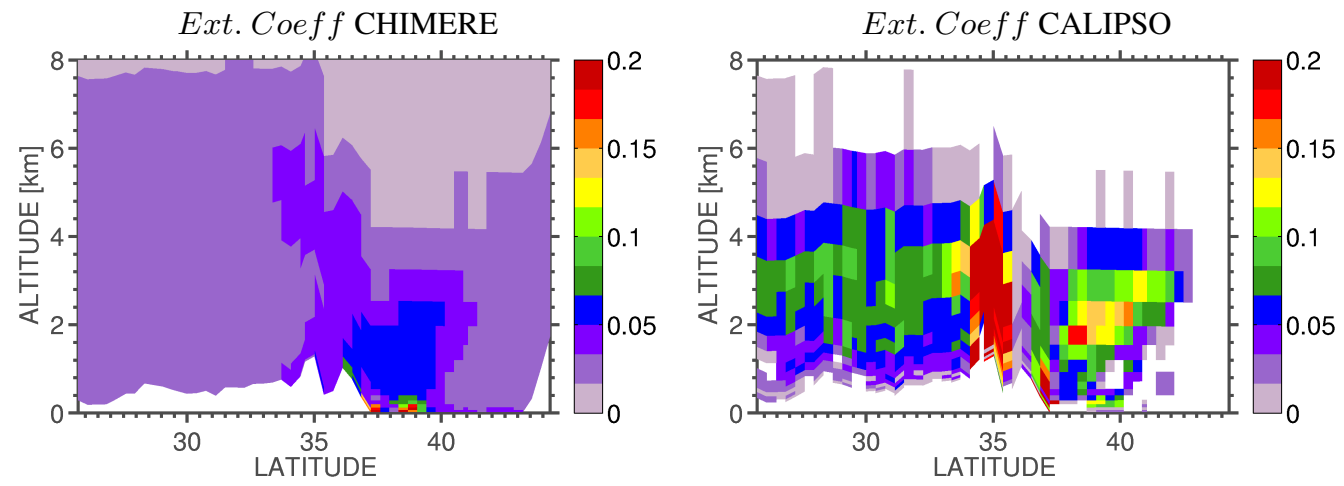

Backsc. Coeff CHIMERE

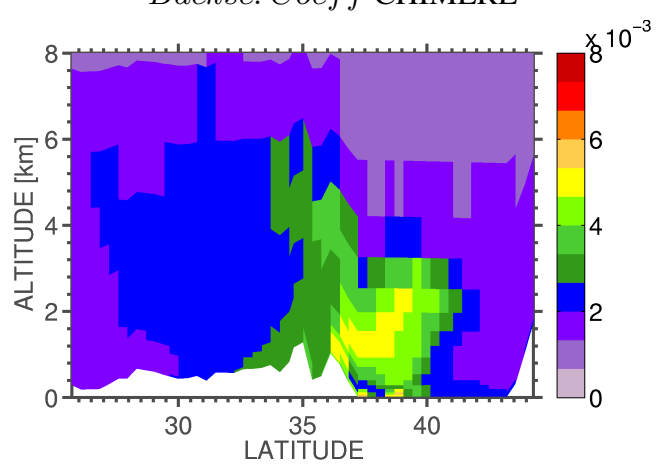

Backsc. Coeff. CALIPSO

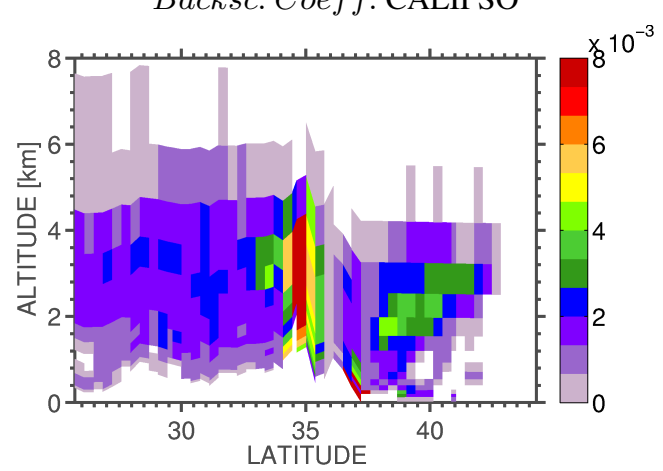

Fig. 13. Extinction $\left(\mathrm{km}^{-1}\right)$ and backscatter $\left(\mathrm{km}^{-1} \mathrm{sr}^{-1}\right)$ coefficient by CHIMERE (left) and CALIOP (right) for the nighttime portion of the orbit of the 9 July 2007. The CALIOP data are averaged into the model's horizontal and vertical resolutions for comparison to the simulated profiles.

$R^{\prime}$ CHIMERE

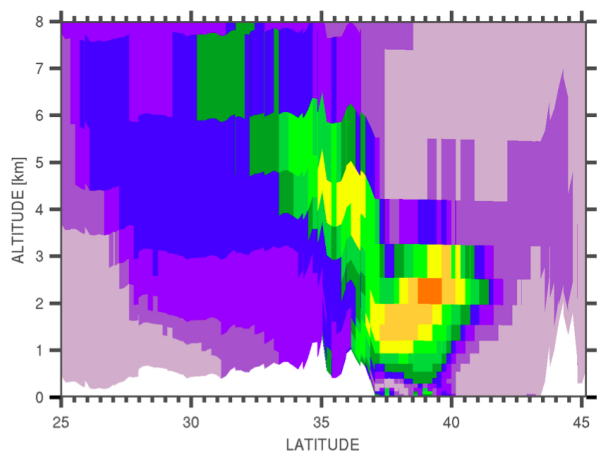

$R^{\prime}$ CALIPSO

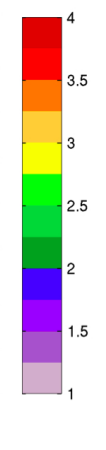

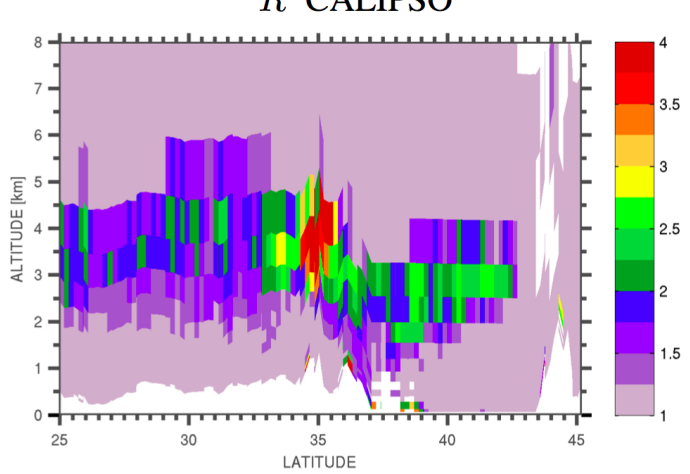

Fig. 14. Attenuated Scattering Ratio by CHIMERE (left) and CALIOP (right) for the nighttime portion of the orbit of the 9 July 2007 . The initial profiles corresponding to cloud contaminated data are filtered out. The cloud-free data are averaged into the model's horizontal and vertical resolutions for comparison to the simulated $R^{\prime}(z)$ profiles.

may be related to a slight temporal shift in the emissions and/or transport. The average maximum simulated $R^{\prime}$ presents a correlation of 0.6 with the observed $R^{\prime}$, a mean bias of 1.12 and a RSME of 0.68 .

For the 14 July 2007 , the simulated $R^{\prime}$ show enhancements around $3-4 \mathrm{~km}$ high above the southern portion of the orbit, which is consistent with the large plume observed at $4 \mathrm{~km}$.
Here again, the model strongly underestimates $R^{\prime}$ and overestimates the vertical extent of the plume.

For the two time periods, the color ratios (Fig. 15 and 16) are underestimated in the model. Examining the first event, the corresponding simulated effective radius $\left(R_{\text {eff }}\right)$ also shown in Fig. 15 presents a maximum $(\sim 1.2-1.3 \mu \mathrm{m})$ near the observed $\chi^{\prime}$ peak, but at a higher altitude. As seen 
$R_{e f f}(\mu m)$ CHIMERE (a)

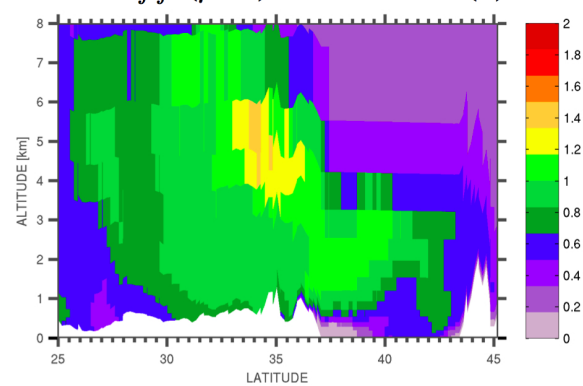

$\chi^{\prime}$ CHIMERE (b)

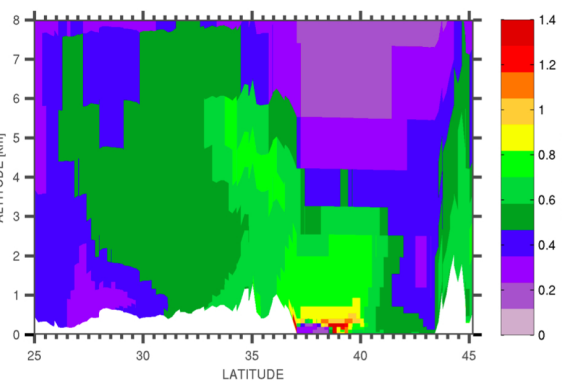

$\chi^{\prime}$ CALIPSO (c)

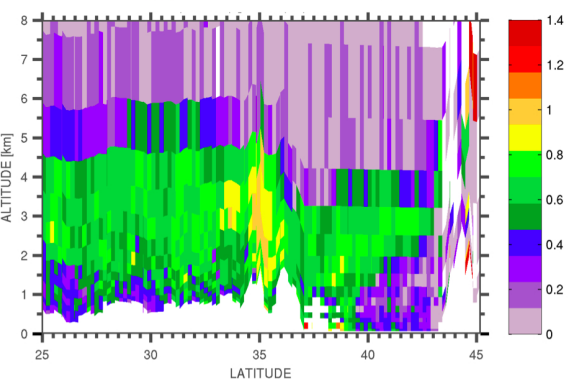

Fig. 15. Effective Radius and Color Ratio by CHIMERE $(\mathbf{a}, \mathbf{b})$ and Color Ratio CALIOP (c) for the nighttime portion of the orbit of the 9 July 2007. The initial profiles corresponding to cloud contaminated data are filtered out. The cloud-free data are averaged into the model's horizontal and vertical resolutions for comparison to the simulated $R^{\prime}(z)$ profiles.
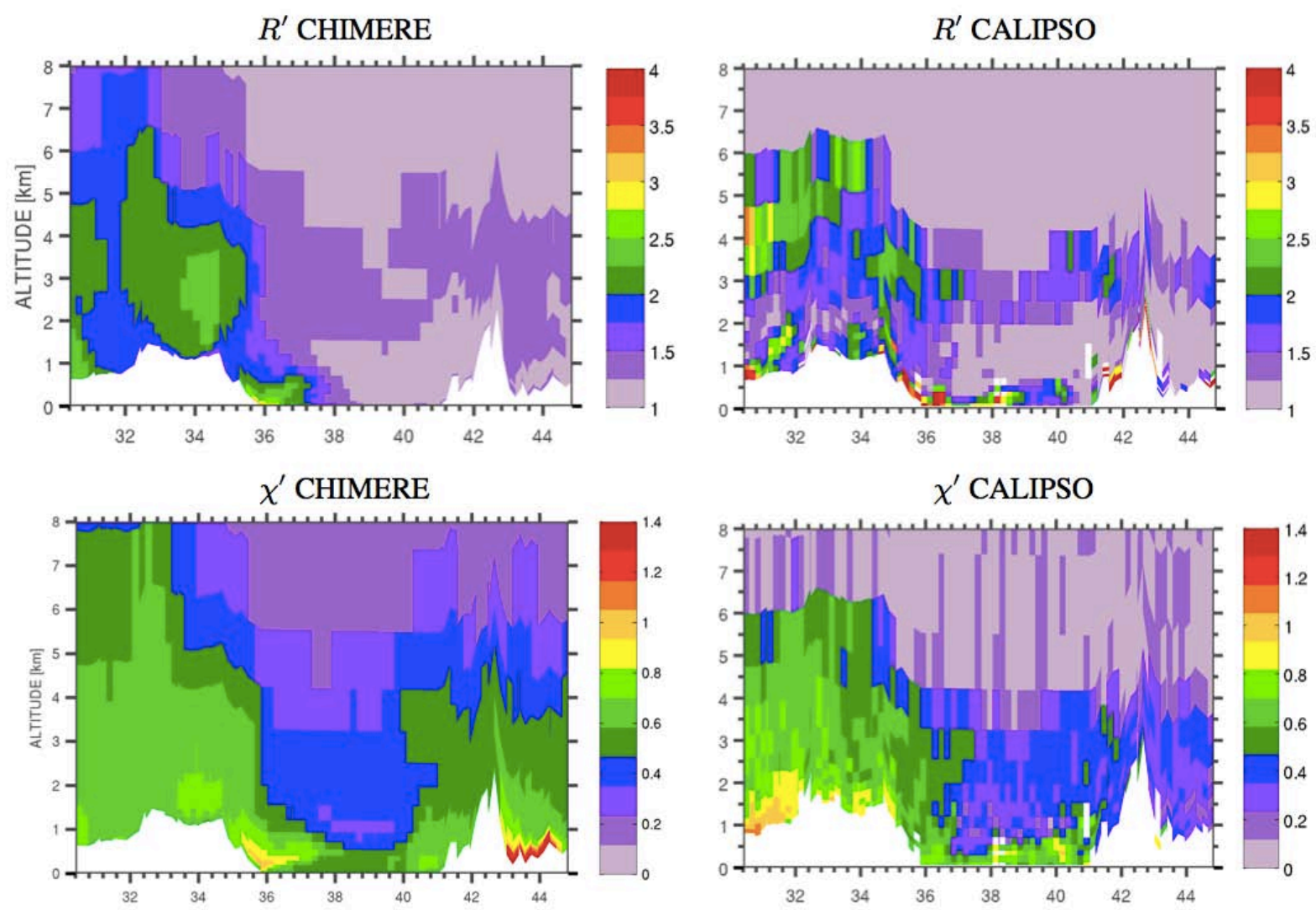

Fig. 16. Same as Fig. 14, but for the nighttime portion of the orbit of the 14 July 2007.

in Fig. 17, it corresponds mostly to dust particles. However, $R_{\text {eff }}$ provides information on the mean size of particles while $\chi^{\prime}$ strongly depends on the size distribution (cf. Fig. 5). For instance, higher $R_{\text {eff }}$ values may be associated with lower $\chi^{\prime}$ values (e.g., $\sim 35^{\circ} \mathrm{N}$ compared to $\sim 39^{\circ} \mathrm{N}$ values) when the concentration in smaller size sections is higher. More specifically, around $\sim 35^{\circ} \mathrm{N}$ at the same altitude as the $R_{\text {eff }}$ peak, the simulated size distribution is dominated by the 8 th size section. By inverting the concentration between the 8th and the 7th, so that the total concentration remains unaltered, we noticed an increase of $63.6 \%$ in $\chi^{\prime}$ along with a $8.4 \%$ decrease in $R_{\text {eff. }}$ This suggests that although the mean size of the particles and their localisation may well represented in the model (consistent with the Angström exponent comparisons), a revision of the dust size distribution would be beneficial for the $\chi^{\prime}$ comparisons. 
(1) $\lambda=5.51, \phi=39.23$

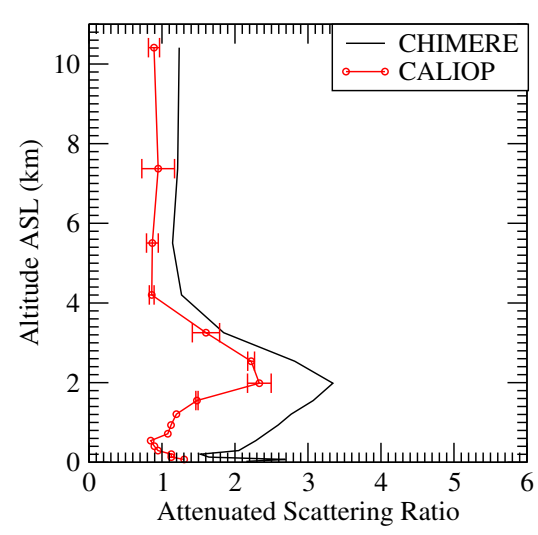

(2) $\lambda=4.23, \phi=35.20$

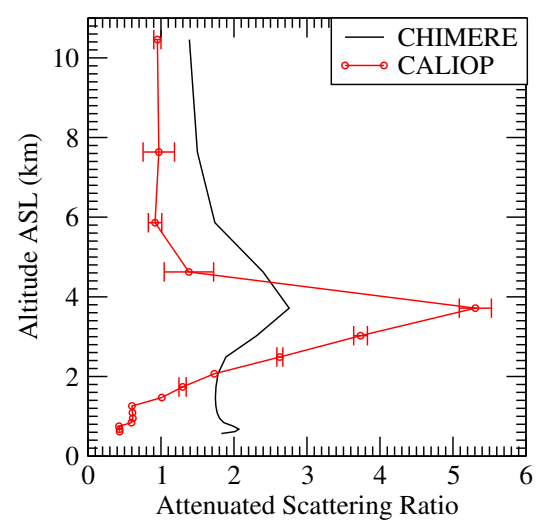

(3) $\lambda=3.97, \phi=33.91$

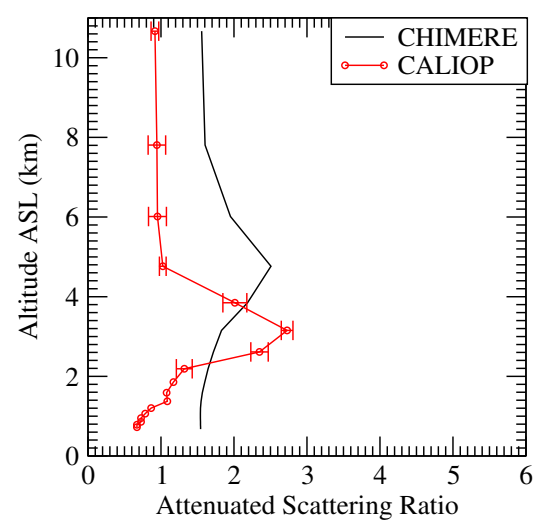

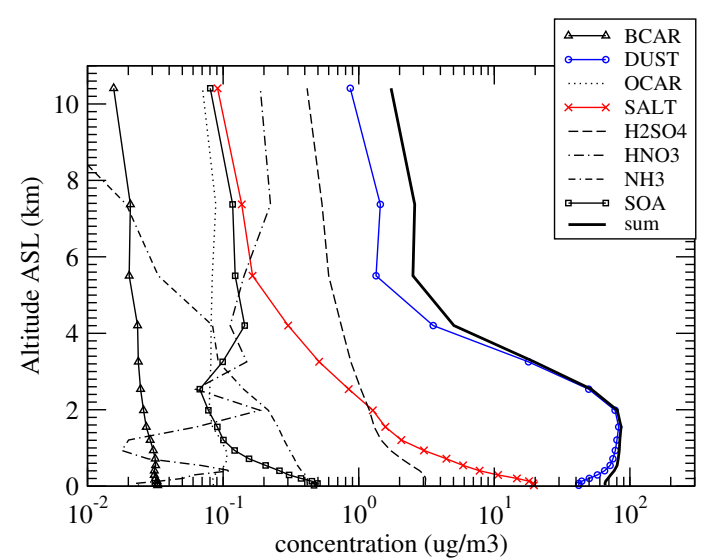
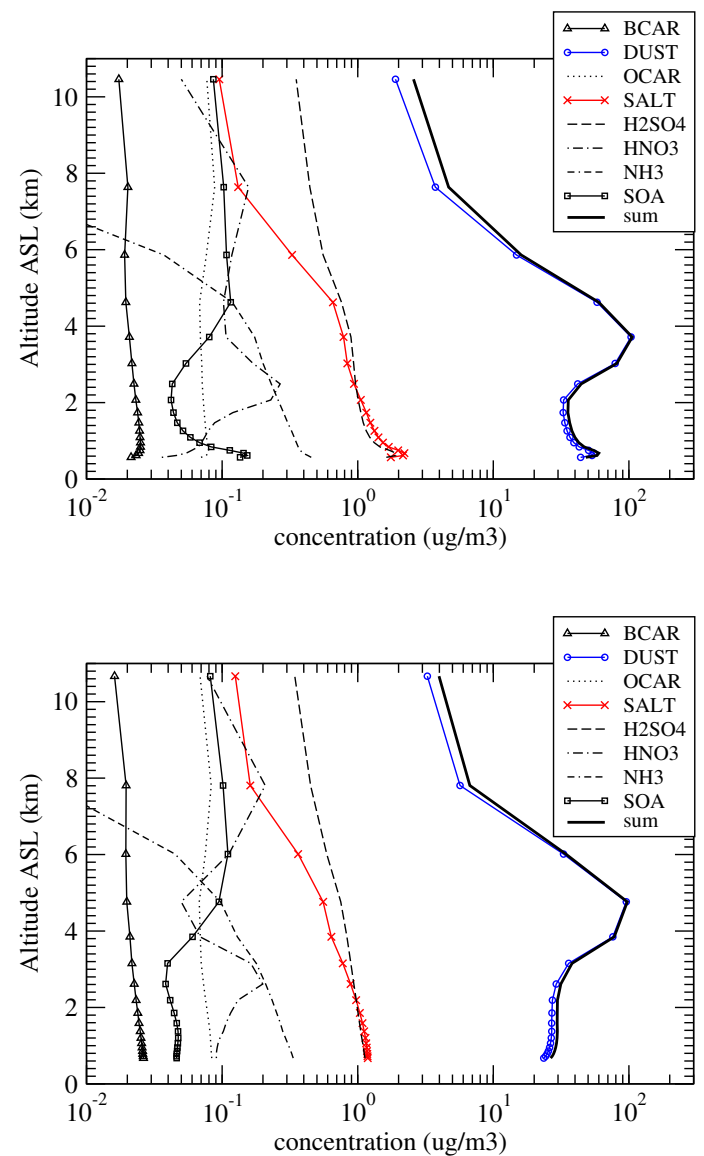

Fig. 17. Scattering Ratio profiles by CALIOP and CHIMERE (left) for the nighttime portion of the orbit the 9 July 2007 and the corresponding CHIMERE concentration profiles per species (right).

The possible missing aerosol sources in the model (cf. Sect. 6.2.1) could also be a cause of discrepancy between the simulated and the observed color ratio.

The main discrepancy in the simulated transport is the vertical extent of the plume. This overestimation in CHIMERE may be due to the chosen vertical resolution, which decreases to $\sim 1 \mathrm{~km}$ in the free troposphere. The comparisons suggest a need for a higher vertical resolution, in order to achieve a better accuracy in terms of layer thickness, which could be 
beneficial to the model's ability to reproduce transport and vertical mixing of atmospheric constituents.

But the vertical diffusion parametrisation in the model may also cause too large transport towards higher altitudes. The $R^{\prime}$ underestimation for the profile closest to the emissions area may be attributed to an underestimation of the dust emissions as we have also seen in the AOD comparisons.

The general features highlighted using comparisons to L1 observations are in consistency with the L2 comparisons. However, in this case, we rely directly on the observed quantity and we do not need to go back to any retrieval classification or assumption.

\section{Conclusions}

In this paper, we presented the OPTSIM post-processing tool, designed for a complete comparison of aerosol concentration distributions calculated by chemistry transport models (CTM) to passive and active remote-sensing observations. By simulating the aerosol optical properties and column integrated parameters (e.g., AOD, Angström exp.) it allows an evaluation of the horizontal and temporal distributions of aerosol compared to passive remote-sensing observations. Furthermore, by simulating lidar attenuated backscattered profiles, the aerosol vertical structures in the model simulations can be directly compared to calibrated Level 1B CALIOP observations. Therefore, it allows additionally, an evaluation of the vertical structure of aerosols and, as a result, the evaluation of the vertical mixing and transport parametrisation in the model. Finally, by simulating color ratio profiles, it can identify problems related to the mean size and the modelled size distribution of aerosols ratio while the contribution of each species to the simulated lidar signal can also be quantified and, therefore, can be used for the study of specific pollution events.

The methodology used and the requirements of the OPTSIM tool in terms of model output configuration are first described. The validation of the simulator's self-consistency is then demonstrated on an academic case study. For two different species (black carbon and dust), the main steps of the calculation from simulated concentration profiles are detailed: optical depth, attenuated backscattered profile, and finally attenuated scattering ratio and color ratio profiles.

An application of this tool is presented for the evaluation of the simulation by the CHIMERE CTM of two specific dust events that took place in the Northwestern African region during July 2007. Firstly, an analysis of these events is conducted based on comparisons to the AERONET and MODIS passive observations only. Then a comparison of the simulated lidar profiles with CALIOP L1 and L2 observations is undertaken. Since we are focusing only on aerosol plumes, the data have to be cloud-filtered before they are averaged on the same horizontal and vertical grid as the model for comparison. The general structure of the dust plume is wellsimulated while the intensity of the examined events appears underestimated. The model appears positively biased regarding the thickness and the altitude of the plume, especially near the emissions area. An assumption of a slight temporal shift in the emissions and/or transport can also be made from the underestimated $R^{\prime}$ values near the observed peak and overestimated values over the Mediterranean sea. These discrepancies may be partly attributed to the vertical mixing parametrization which may have to be revised with the addition of finer altitude layers.

This work shows the additional information that can be expected from the use of lidar observation for the analysis of long-range transport events. However, due to their limited horizontal coverage, the complementary use of passive remote-sensing observations is necessary for further validation of the emissions and horizontal transport pathways.

The OPTSIM tool described in this paper could be also used as an observation operator in data assimilation studies, coupled with a cloud signal/noise simulator. Furthermore, it is designed to be model independent and can be adapted for other CTMs. It can be provided upon request to any interested user.

Acknowledgements. The authors are grateful to the French ICARE database (http://www.icare.univ-lille1.fr/) for providing the MODIS and CALIPSO data. The MODIS and CALIPSO project and science teams are greatly acknowledged for data availability as well as CLIMSERV/CGTD for providing access to the Level 1 CALIPSO dataset. We also thank D. Winker, for helpful comments. The authors acknowledge the Centre National des Etudes Spatiales (CNES, France) for financial support. S. Stromatas is supported by a fellowship from the CNES and the Agence de l'Environnement et de la Maitrîse de l'Energie (ADEME, France).

Edited by: V. Grewe

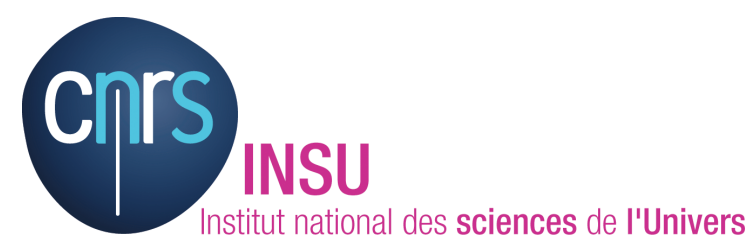

The publication of this article is financed by CNRS-INSU.

\section{References}

Andreae, M. O. and Merlet, P.: Emission of trace gases and aerosols from biomass burning, Global Biogeochem. Cy., 15, 995-966, 2001.

Bessagnet, B., Hodzic, A., Vautard, R., Beekmann, M., Cheinet, S., Honore, C., Liousse, C., and Rouil, L.: Aerosol modelling with CHIMERE - preliminary evaluation at the continental scale, Atmos. Environ., 38, 2803-2817, 2004.

Bessagnet, B., Menut, L., Aymoz, G., Chepfer, H., and Vautard, R.: Modeling dust emissions and transport within Europe: 
the Ukraine March 2007 event, J. Geophys. Res., 113, D15202, doi:10.1029/2007JD009541, 2008.

Bessagnet, B., Menut, L., Curci, G., Hodzic, A., Guillaume, B., Liousse, C., Moukhtar, S., Pun, B., Seigneur, C., and Schulz, M.: Regional modelling of carbonaceous aerosols over Europe - focus on secondary organic aerosols, J. Atmos. Chem., 61, 175202, 2009.

Bessagnet, B., Seigneur, C., and Menut, L.: Impact of dry deposition of semi-volatile organic compounds on secondary organic aerosols, Atmos. Environ., 44, 1781-1787, doi:10.1016/j.atmosenv.2010.01.027, 2010.

Bey, I., Jacob, D. J., Yantosca, R. M., Logan, J. A., Field, B. D., Fiore, A. M., Li, Q., Liu, H. Y., Mickley, L. J., and Schultz, M. G.: Global modelling of tropospheric chemistry with assimilated meteorology: Model description and evaluation J. Geophys. Res., 106, 23073-23096, doi:10.1029/2001JD000807, 2001.

Bréon, F., Vermeulen, A., and Descloitres, J.: An evaluation of satellite aerosol products against sunphotometer measurements, Remote Sens. Environ., 115, 3102-3111, 2011.

Chen, F. and Dudhia, J.: Coupling an advanced land surfacehydrology model with the Penn State-NCAR MM5 modelling system. Part I: model implementation and sensitivity, Mon. Weather Rev., 129, 569-585, 2001.

Chepfer, H., Bony, S., Winker, D., Chiriaco, M., Dufresne, J., and Sèze, G.: Use of CALIPSO lidar observations to evaluate the cloudiness simulated by a climate model, Geophys. Res. Lett., 35, L15704, doi:10.1029/2008GL034207, 2008.

Chepfer, H., Bony, S., Winker, D., Cesana, G., Dufresne, J. L., Minnis, P., Stubenrauch, C. J., and Zeng, S.: The GCM Oriented CALIPSO Cloud Product (CALIPSO-GOCCP), J. Geophys. Res., 115, D00H16, doi:10.1029/2009JD012251, 2010.

Chepfer, H., Cesana, G., Winker, D., Getzewich, B., and Vaughan, M.: Comparison of two different cloud climatologies derived from CALIOP Level 1 observations: the CALIPSOST and the CALIPSO-GOCCP, J. Atmos. Ocean. Tech., 10.1175/JTECH-D-12-00057.1, 2012.

Collins, R. T. H. and Russell, P. B.: Lidar measurement of particles and gases by elastic backscattering and differential absorption, Top. Appl. Phys., 14, 71-151, 1976.

de Rooij, W. A. and van der Stap, C. C. A. H.: Expansion of Mie scattering matrices in generalized spherical functions, Astron. Astrophys., 131, 237-248, 1984.

de Villiers, R. A., Ancellet, G., Pelon, J., Quennehen, B., Schwarzenboeck, A., Gayet, J. F., and Law, K. S.: Airborne measurements of aerosol optical properties related to early spring transport of mid-latitude sources into the Arctic, Atmos. Chem. Phys., 10, 5011-5030, doi:10.5194/acp-10-5011-2010, 2010.

Dubovik, O. and King, M.: A flexible inversion algorithm for retrieval of aerosol optical properties from sun and sky radiance measurements, J. Geophys. Res., 105, 20673-20696, 2000.

Dubovik, O., Smirnov, A., Holben, B. N., King, M. D., Kaufman, Y. J., Eck, T. F., and Slutsker, I.: Accuracy assessments of aerosol optical properties retrieved from Aerosol Robotic Network (AERONET) sun and sky radiance measurements, J. Geophys. Res., 105, 9791-9806, 2000.

Dubovik, O., Holben, B. N., Eck, T., Smirnov, A., Kaufman, Y. J., King, M. D., Tanré, D., and Slutsker, I.: Variability of absorption and optical properties of key aerosol types observed in worldwide locations, J. Atmos. Sci., 59, 590-608, 2002a.
Dubovik, O., Holben, B. N., Lapyonok, T., Sinyuk, A., Mishchenko, M. I., Yang, P., and Slutsker, I.: Non-spherical aerosol retrieval method employing light scattering by spheroids, Geosphys. Res. Lett, 29, 1415, doi:10.1029/2001GL014506, 2002b.

Dubovik, O., Lapyonok, T., Kaufman, Y. J., Chin, M., Ginoux, P., Kahn, R. A., and Sinyuk, A.: Retrieving global aerosol sources from satellites using inverse modelling, Atmos. Chem. Phys., 8, 209-250, doi:10.5194/acp-8-209-2008, 2008.

Escudero, M., Querol, X., Avila, A., and Cuevas, E.: Origin of the exceedances of the European daily PM limit value in regional background areas of Spain, Atmos. Environ., 41, 730-744, 2007.

Ford, B. and Heald, C. L.: An A-Train and model perspective on the vertical distribution of aerosols and $\mathrm{CO}$ in the Northern Hemisphere, J. Geophys. Res., 117, D06211, doi:10.1029/2011JD016977, 2012.

Forster, P., Ramaswamy, V., Artaxo, P., Berntsen, T., Betts, R., Fahey, D., Haywood, J., Lean, J., Lowe, D., Myhre, G., Nganga, J., Prinn, R., Raga, G., Schulz, M., and Dorland, R. V.: Changes in atmospheric constituents and in radiative forcing, in: Climate Change 2007: The Physical Science Basis. Contribution of Working Group I to the Fourth Assessment Report of the Intergovernmental Panel on Climate Change, edited by: Solomon, S., Qin, D., Manning, M., Chen, Z., Marquis, M., Averyt, K. B., Tignor, M., and Miller, H. L., Cambridge University Press, Cambridge, UK and New York, NY, USA, 2007.

Gasteiger, J., Wiegner, M. Groß, S., Freudenthaler, V. Toledano, C., Tesche, M., and Kandler, K.: Modelling lidar-relevant optical properties of complex mineral dust aerosols, Tellus B, 63, 725741, doi:10.1111/j.1600-0889.2011.00559.x., 2011.

Generoso, S., Bey, I., Labonne, M., and Bréon, F. M.: Aerosol vertical distribution in dust outflow over the Atlantic: comparisons between GEOS-Chem and Cloud-Aerosol Lidar and Infrared Pathfinder Satellite Observation (CALIPSO), J. Geophys. Res., 113, D24209, doi:10.1029/2008JD010154, 2008.

Gobbi, G., Barnaba, F., and Ammannat, L.: Estimating the impact of Saharan dust on the year $2001 \mathrm{PM}_{10}$ record of Rome, Italy, Atmos. Environ., 41, 261-275, 2007.

Gordon, H.: Atmospheric correction of ocean color imagery in the Earth Observing System era, J. Geophys. Res., 102, 1708117106, 1997.

Grell, G. A. and Devenyi, D.: A generalized approach to parameterizing convection combining ensemble and data assimilation techniques, Geophys. Res. Lett., 29, 1693, doi:10.1029/2002GL015311, 2002.

Guenther, A., Karl, T., Harley, P., Wiedinmyer, C., Palmer, P. I., and Geron, C.: Estimates of global terrestrial isoprene emissions using MEGAN (Model of Emissions of Gases and Aerosols from Nature), Atmos. Chem. Phys., 6, 3181-3210, doi:10.5194/acp-63181-2006, 2006.

Hallquist, M., Wenger, J. C., Baltensperger, U., Rudich, Y., Simpson, D., Claeys, M., Dommen, J., Donahue, N. M., George, C., Goldstein, A. H., Hamilton, J. F., Herrmann, H., Hoffmann, T., Iinuma, Y., Jang, M., Jenkin, M. E., Jimenez, J. L., KiendlerScharr, A., Maenhaut, W., McFiggans, G., Mentel, Th. F., Monod, A., Prévôt, A. S. H., Seinfeld, J. H., Surratt, J. D., Szmigielski, R., and Wildt, J.: The formation, properties and impact of secondary organic aerosol: current and emerging issues, Atmos. Chem. Phys., 9, 5155-5236, doi:10.5194/acp-9-5155- 
2009, 2009.

Hänel, G.: The properties of atmospheric particles as functions of the relative humidity at thermodynamic equilibrium with surrounding moist air, Adv. Geophys., 19, 73-188, 1976.

Heald, C., Ridley, D., Kreidenweis, S., and Drury, E. E.: Satellite observations cap the atmospheric organic aerosol budget, Geophys. Res. Lett., 37, L24808, doi:10.1029/2010GL045095, 2010.

Hodzic, A., Chepfer, H., Vautard, R., Chazette, P., Beekmann, M., Bessagnet, B., Chatenet, B., Cuesta, J., Drobinski, P., Goloub, P., Haeffelin, M., and Morille, Y.: Comparison of aerosol chemistry transport model simulations with lidar and sun photometer observations at a site near Paris, J. Geophys. Res., 109, D23201, doi:10.1029/2004JD004735, 2004.

Hodzic, A., Madronich, S., Bohn, B., Massie, S., Menut, L., and Wiedinmyer, C.: Wildfire particulate matter in Europe during summer 2003: meso-scale modelling of smoke emissions, transport and radiative effects, Atmos. Chem. Phys., 7, 4043-4064, doi:10.5194/acp-7-4043-2007, 2007.

Holben, B., Eck, T., Slutsker, I., Tanré, D., Buis, J., Setzer, A., Vermote, E., Reagan, J., Kaufman, Y., Nakajima, T., Lavenu, F., Jankowiak, I., and Smirnov, A.: AERONET: a federated instrument network and data archive for aerosol characterization, Remote Sens. Environ., 66, 1-16, 1998.

Hong, S. Y., Dudhia, J., and Chen, S.: A revised approach to ice microphysical processes for the bulk parameterization of clouds and precipitation, Mon. Weather Rev., 132, 103-120, 2004.

Hong, S. Y., Noh, Y., and Dudhia, J.: A new vertical diffusion package with an explicit treatment of entrainment processes, Mon. Weather Rev., 134, 2318-2341, doi:10.1175/MWR3199.1, 2006.

Hostetler, C. A., Liu, Z., Reagan, J., Vaughan, M., Winker, D., Osborn, M., Hunt, W. H., Powell, K. A., and Trepte, C.: CALIOP Algorithm Theoretical Basis Document, Calibration and level 1 Data Products, PC-SCI-201, NASA Langley Research Center, Hampton, VA 23681, available online at http://www-calipso.larc. nasa.gov/resources/project documentation.php, 2006.

Huneeus, N., Schulz, M., Balkanski, Y., Griesfeller, J., Prospero, J., Kinne, S., Bauer, S., Boucher, O., Chin, M., Dentener, F., Diehl, T., Easter, R., Fillmore, D., Ghan, S., Ginoux, P., Grini, A., Horowitz, L., Koch, D., Krol, M. C., Landing, W., Liu, X., Mahowald, N., Miller, R., Morcrette, J.-J., Myhre, G., Penner, J., Perlwitz, J., Stier, P., Takemura, T., and Zender, C. S.: Global dust model intercomparison in AeroCom phase I, Atmos. Chem. Phys., 11, 7781-7816, doi:10.5194/acp-11-7781-2011, 2011.

Hunt, W. H., Winker, D. M., Vaughan, M. A., Powell, K. A., Lucker, P. L., and Weimer, C.: CALIPSO lidar description and performance assessment, J. Atmos. Ocean. Tech., 7, 1214-1228, 2009.

Kaskaoutis, D., Kambezidis, H., Nastos, P., and Kosmopoulos, P.: Study on an intense dust storm over Greece, Atmos. Environ., 42, 6884-6896, 2008.

Kaufman, Y. J., Boucher, O., Tanré, D., Chin, M., Remer, L. A., and Takemura, T.: Aerosol anthropogenic component estimated from satellite data, Geophys. Res. Lett., 32, L17804, doi:10.1029/2005GL023125, 2005.

Keating, T. J. and Zuber, A.: Hemispheric Transport of Air Pollution 2007 Interim Report, United Nations, Economic Commission for Europe, Geneva, 2007.

Koch, D., Schulz, M., Kinne, S., McNaughton, C., Spackman, J. R., Balkanski, Y., Bauer, S., Berntsen, T., Bond, T. C., Boucher, O.,
Chin, M., Clarke, A., De Luca, N., Dentener, F., Diehl, T., Dubovik, O., Easter, R., Fahey, D. W., Feichter, J., Fillmore, D., Freitag, S., Ghan, S., Ginoux, P., Gong, S., Horowitz, L., Iversen, T., Kirkevåg, A., Klimont, Z., Kondo, Y., Krol, M., Liu, X., Miller, R., Montanaro, V., Moteki, N., Myhre, G., Penner, J. E., Perlwitz, J., Pitari, G., Reddy, S., Sahu, L., Sakamoto, H., Schuster, G., Schwarz, J. P., Seland, Ø., Stier, P., Takegawa, N., Takemura, T., Textor, C., van Aardenne, J. A., and Zhao, Y.: Evaluation of black carbon estimations in global aerosol models, Atmos. Chem. Phys., 9, 9001-9026, doi:10.5194/acp-9-9001-2009, 2009.

Konsta, D., Chepfer, H., and Dufresne, J.: A process oriented description of tropical oceanic clouds for climate model evaluation, based on a statistical analysis of daytime A-train high spatial resolution observations, Clim. Dynam., 10.1007/s00382-012-15337, 2012.

Koren, I., Oreopoulos, L., Feingold, G., Remer, L. A., and Altaratz, O.: How small is a small cloud?, Atmos. Chem. Phys., 8, 3855-3864, doi:10.5194/acp-8-3855-2008, 2008.

Laurent, B., Marticorena, B., Bergametti, G., Léon, J. F., and Mahowald, N. M.: Modeling mineral dust emissions from the Sahara desert using new surface properties and soil database, J. Geophys. Res., 113, D14218, doi:10.1029/2007JD009484, 2008.

Lelieveld, J., Berresheim, H., Borrmann, S., Crutzen, P. J., Dentener, F. J., Fischer, H., Feichter, J., Flatau, P. J., Heland, J., Holzinger, R., Korrmann, R., Lawrence, M. G., Levin, Z., Markowicz, K. M., Mihalopoulos, N., Minikin, A.,Ramanathan, V., de Reus, M., Roelofs, G. J., Scheeren, H. A., Sciare, J., Schlager, H., Schultz, M., Siegmund, P., Steil, B., Stephanou, E. G., Stier, P., Traub, M., Warneke, C., Williams, J., and Ziereis, H.: Global air pollution crossroads over the Mediterranean, Science, 298, 794, doi:10.1126/science.1075457, 2002.

Levy, R. C., Remer, L. A., Kleidman, R. G., Mattoo, S., Ichoku, C., Kahn, R., and Eck, T. F.: Global evaluation of the Collection 5 MODIS dark-target aerosol products over land, Atmos. Chem. Phys., 10, 10399-10420, doi:10.5194/acp-10-10399-2010, 2010.

Liu, Z., Omar, A., Vaughan, M., Hair, J., and Kittaka, C.: CALIPSO lidar observations of the optical properties of Saharan dust: a case study of long-range transport, J. Geophys. Res., 113, D07207, doi:10.1029/2007JD008878, 2008.

Liu, Z., Vaughan, M., Winker, D., Kittaka, C., Getzewich, B., Kuehn, R., Omar, A., Powell, K., Trepte, C., and Hostetler, C.: The CALIPSO lidar cloud and aerosol discrimination: version 2 algorithm and initial assessment of performance, J. Atmos. Ocean. Tech., 26, 1198-1213, 2009.

Liu, Z., Winker, D., Omar, A., Vaughan, M., Trepte, C., Hu, Y., Powell, K., Sun, W., and Lin, B.: Effective lidar ratios of dense dust layers over North Africa derived from the CALIOP measurements, J. Quant. Spectrosc. Ra., 112, 204-213, doi:10.1016/j.jqsrt.2010.05.006, 2011.

Mattis, I., Ansmann, A., Müller, D., Wandinger, U., and Althausen, D.: Dual-wavelength Raman lidar observations of the extinction-to-backscatter ratio of Saharan dust, Geophys. Res. Lett. 29, doi:10.1029/2002GL014721, 2002.

Medeiros, B., Nuijens, L., Antoniazzi, C., and Stevens, B.: Lowlatitude boundary layer clouds as seen by CALIPSO, J. Geophys. Res., 115, D23207, doi:10.1029/2010JD014437, 2010.

Menut, L.: Sensitivity of hourly Saharan dust emissions to NCEP and ECMWF modelled wind speed, J. Geophys. Res.-Atmos., 
113, D16201, doi:10.1029/2007JD009522, 2008.

Menut, L., Goussebaile, A., Bessagnet, B., Khvorostiyanov, D., and Ung, A.: Impact of realistic hourly emissions profiles on modelled air pollutants concentrations, Atmos. Environ., 49 , 233244, 2012.

Mishchenko, M. I., Travis, L. D., Kahn, R. A. and West, R. A.: Modeling phase functions for dust-like tropospheric aerosols using a shape mixture of randomly oriented polydisperse spheroids, J. Geophys. Res., 102, 16831-16847, 1997.

Mlawer, E., Taubman, S., Brown, P., Iacono, M., and Clough, S.: Radiative transfer for inhomogeneous atmospheres: RRTM a validated correlated-k model for the longwave, J. Geophys. Res., 102, 16663-16682, 1997.

Monks, P. S., Granier, C., Fuzzi, S., Stohl, A., Williams, M. L. Akimoto, H., Amann, M., Baklanov, A., Baltensperger, U., Bey, I., Blake, N., Blake, R. S., Carslaw, K., Cooper, O. R., Dentener, F., Fowler, D., Fragkou, E., Frost, G. J., Generoso, S., Ginoux, P., Grewe, V., Guenther, A., Hansson, H. C., Henne, S., Hjorth, J., Hofzumahaus, A., Huntrieser, H., Isaksen, I. S. A., Jenkin, M. E., Kaiser, J., Kanakidou, M., Klimont, Z., Kulmala, M., Laj, P., Lawrence, M. G., Lee, J. D., Liousse, C., Maione, M., McFiggans, G., Metzger, A., Mieville, A., Moussiopoulos, N., Orlando, J. J., O’Dowd, C. D., Palmer, P. I., Parrish, D. D., Petzold, A., Platt, U., Poschl, U., Prevot, A. S. H., Reeves, C. E., Reimann, S., Rudich, Y., Sellegri, K., Steinbrecher, R., Simpson, D., ten Brink, H., Theloke, J., van der Werf, G., Vautard, R., Vestreng, V., Vlachokostas, Ch., and von Glasow, R.: Atmospheric composition change global and regional air quality, Atmos. Environ., 43, 5268-5350, doi 10.1016/j.atmosenv.2009.08.021, 2009.

Müller, D., Mattis, I., Wandinger, U., Althausen, D., Ansmann, A., Dubovik, O., Eckhardt, S., and Stohl, A.: Saharan dust over a Central European EARLINET-AERONET site: Combined observations with Raman lidar and Sun photometer, J. Geophys. Res., 108, 4345, doi:10.1029/2002JD002918, 2003

Nenes, A., Pilinis, C., and Pandis, S.: ISORROPIA: a new thermodynamic model for inorganic multicomponent atmospheric aerosols, Aquat. Geochem., 4, 123-152, 1998.

Omar, A., Winker, D. M., Vaughan, M. A., Hu, Y., Trepte, C. R., Ferrare, R. A., Lee, K.-P., Hostetler, C. A., Kittaka, C., Rogers, R. R., Kuehn, R. E., and Liu, Z.: The CALIPSO automated aerosol classification and lidar ratio selection algorithm, J. Atmos. Ocean. Tech., 26, 1994-2014, 2010.

Péré, J. C., Mallet, M., Bessagnet, B., and Pont, V.: Evidence of the aerosol core-shell mixing state over Europe during the heat wave of summer 2003 by using CHIMERE simulations and AERONET inversions, Geophys. Res. Lett., 36, L09807, doi:10.1029/2009GL037334, 2009.

Péré, J., Mallet, M., Pont, V., and Bessagnet, B.: Evaluation of an aerosol optical scheme in the chemistry transport model CHIMERE, Atmos. Environ., 44, 3688-3699, doi:10.1016/j.atmosenv.2010.06.034, 2010.

Pope, C. A., Burnett, R. T., Thun, M. J., Calle, E. E., Krewski, D., and Thurston, K. I. G. D.: Lung cancer, cardiopulmonary mortality, and long-term exposure to fine particulate air pollution, JAMA-J. Am. Med. Assoc., 287, 1132-1141, 2002.

Powell, K. A., Hostetler, C. A., Liu, Z., Vaughan, M. A., Kuehn, R. E., Hunt, W. H., Lee, K.-P., Trepte, C. R., Rogers, R. R., Young, S. A., and Winker, D. M.: CALIPSO lidar calibration algorithms.
Part I: nighttime $532 \mathrm{~nm}$ parallel channel and $532 \mathrm{~nm}$ perpendicular channel, J. Atmos. Ocean. Tech., 26, 2015-2033, 2009.

Putaud, J.-P., Van Dingenen, R., Alastuey, A., Bauer, H., Birmili, W., Cyrys J., Flentje, H., Fuzzi, S., Gehrig, R., Hansson, H. C., Harrison, R. M., Herrmann, H., Hitzenberger, R., Hüglin, C., Jones, A. M., Kasper-Giebl, A., Kiss, G., Kousam, A., Kuhlbusch, T. A. J., Löschau, G., Maenhaut, W., Molnar, A., Moreno, T., Pekkanen, J., Perrino, C., Pitz, M., Puxbaumc, H., Querol, X., Rodriguez, S., Salma, I., Schwarz, J., Smolik, J., Schneider, J., Spindler, G., ten Brink, H., Tursic, J., Viana, M., Wiedensohler, A., and Raes, F.: A European aerosol phenomenology - 3: physical and chemical characteristics of particulate matter from 60 rural, urban, and kerbside sites across Europe, Atmos. Environ., 44, 1308-1320, 2010.

Querol, X., Pey, J., Pandolfi, M., Alastuey, A., Cusack, M., Pereza, N., Moreno, T., Viana, M., Mihalopoulos, N., Kallo, G., and Kleanthous, S.: African dust contributions to mean ambient $\mathrm{PM}_{10}$ mass-levels across the Mediterranean Basin, Atmos. Environ., 43, 4266-4277, 2009.

Remer, L. A., Kaufman, Y. J., Tanré, D., Mattoo, S., Chu, D. A., Martins, J. V., Li, R.-R., Ichoku, C., Levy, R. C., Kleidman, R. G., Eck, T. F., Vermote, E., and Holben, B. N.: The MODIS aerosol algorithm, products and validation, special section, J. Atmos. Sci., 62, 947-973, 2005.

Ridley, D. A., Heald, C. L., and Ford, B.: North African dust export and deposition: a satellite and model perspective, J. Geophys. Res., 117, D02202, doi:10.1029/2011JD016794, 2012.

Rothman, L. S., Gordon, I. E., Barbe, A., Chris Benner, D., Bernath, P. F., Birk, M., Boudon, V., Brown, L. R., Campargue, A., Champion, J.-P., Chance, K., Coudert, L. H., Dana, V., Devi, V. M., Fally, S., Flaud, J.-M., Gamache, R. R., Goldmanm, A., Jacquemart, D., Kleiner, I., Lacome, N., Lafferty, W. J., Min, J.-Y., Massie, S. T., Mikhailenko, S. N., Miller, C. E., Moazzen-Ahmadi, N., Naumenko, O. V., Nikitin, A. V., Orphal, J., Perevalov, V. I., Perrin, A., Predoi-Cross, A., Rinsl, C. P., Rotger, M., Šimečková, M., Smith, M. A. H., Sung, K., Tashkun, S. A., Tennyson, J., Toth, R. A., V aele, A. C., and Ver Auwera, J.: The HITRAN 2008 molecular spectroscopic database, J. Quant. Spectrosc. Ra., 100, 533-572, 2009.

Rouil, L., Honore, C., Vautard, R., Beekmann, M., Bessagnet, B., Malherbe, L., Meleux, F., Dufour, A., Elichegaray, C., Flaud, J., Menut, L., Martin, D., Peuch, A., Peuch, V., and Poisson, N.: PREV'AIR: an operational forecasting and mapping system for air quality in Europe, B. Am. Meteorol. Soc., 90, 73-83, doi:10.1175/2008BAMS2390.1, 2009.

Schmidt, H., Derognat, C., Vautard, R., and Beekmann, M.: A comparison of simulated and observed ozone mixing ratios for the summer of 1998 in Western Europe, Atmos. Environ., 35, 62776297, 2001.

Schmidt, G. L., Vaughan, M., MacDonnell, D., Su, W., Dubovik, O., Lapyonok, T., and Trepte, C.: Comparison of CALIPSO aerosol optical depth retrievals to AERONET measurements, and a climatology for the lidar ratio of dust, Atmos. Chem. Phys., 12, 7431-7452, doi:10.5194/acp-12-7431-2012, 2012.

Shinn, E., Smith, G., Prospero, J., Betzer, P., Hayes, M., Garrison, V., and Barber, R.: African dust and the demise of caribbean coral reefs, Geophys. Res. Lett., 27, 3029-3032, 2000.

Stern, R., Builtjes, P., Schaap, M., Timmermans, R. Vautard, R., Hodzic, A., Memmesheimer, M., Feldmann, H., Renner, E., 
Wolke, R., and Kerschbaumer, A.: A model inter-comparison study focussing on episodes with elevated PM10 concentrations, Atmos. Environ., 42, 19, 4567-4588, 2008.

Stohl, A., Eckhardt, S., Forster, C., James, P., and Spichtinger, N.: On the pathways and timescales of intercontinental air pollution transport, J. Geophys. Res., 107, 4684, 10.1029/2001JD001396, 2002.

Tanré, D., Bréon, F. M., Deuzé, J. L., Dubovik, O., Ducos, F., François, P., Goloub, P., Herman, M., Lifermann, A., and Waquet, F.: Remote sensing of aerosols by using polarized, directional and spectral measurements within the A-Train: the PARASOL mission, Atmos. Meas. Tech., 4, 1383-1395, doi:10.5194/amt-4-1383-2011, 2011.

Textor, C., Schulz, M., Guibert, S., Kinne, S., Balkanski, Y., Bauer, S., Berntsen, T., Berglen, T., Boucher, O., Chin, M., Dentener, F., Diehl, T., Feichter, J., Fillmore, D., Ginoux, P., Gong, S., Grini, A., Hendricks, J., Horowitz, L., Huang, P., Isaksen, I. S. A., Iversen, T., Kloster, S., Koch, D., Kirkevåg, A., Kristjansson, J. E., Krol, M., Lauer, A., Lamarque, J. F., Liu, X., Montanaro, V., Myhre, G., Penner, J. E., Pitari, G., Reddy, M. S., Seland, Ø., Stier, P., Takemura, T., and Tie, X.: The effect of harmonized emissions on aerosol properties in global models an AeroCom experiment, Atmos. Chem. Phys., 7, 4489-4501, doi:10.5194/acp-7-4489-2007, 2007.

Toon, O. and Ackerman, T.: Algorithms for the calculation of scattering by stratified spheres, Appl. Optics, 20, 3657-3660, 1981.

van Donkelaar, A., Martin, R. V., and Park, R. J.: Estimating ground-level $\mathrm{PM}_{2.5}$ using aerosol optical depth determined from satellite remote sensing, J. Geophys. Res., 111, D21201, doi:10.1029/2005JD006996, 2006.

Vautard, R., Bessagnet, B., Chin, M., and Menut, L.: On the contribution of natural Aeolian sources to particulate matter concentrations in Europe: testing hypotheses with a modelling approach, Atmos. Environ., 39, 3291-3303, 2005.

Vautard, R., Maidi, M., Menut, L., Beekmann, M., and Colette, A.: Boundary layer photochemistry simulated with a two-stream convection scheme, Atmos. Environ., 41, 8275-8287, 2007.

Vuolo, M., Chepfer, H., Menut, L., and Cesana, G.: Comparison of mineral dust layers vertical structures modelled with CHIMEREDUST and observed with the CALIOP lidar, J. Geophys Res.Atmos, 114, D09214, doi:10.1029/2008JD011219, 2009.
Wandinger, U., Tesche, M., Seifert, P., Ansmann, A., Müller, D., and Althausen, D.: Size matters: influence of multiple scattering on CALIPSO lightextinction profiling in desert dust, Geophys. Res. Lett., 37, L10801, doi:10.1029/2010GL042815, 2010.

Wang, K., Dickinson, R. E., and Liang, S.: Clear sky visibility has decreased clear sky visibility has decreased over land globally from 1973 to 2007, Science, 323, 1468-1470, 2009.

Waquet, F., Riédi, J., Labonnote, L.-C., Goloub, P., Cairns, B., Deuzé, J.-L., and Tanré, D.: Aerosol remote sensing over clouds using A-Train observations, J. Atmos. Sci., 66, 2468-2480, 2009.

Winker, D. M., Vaughan, A. O., Hu, Y., Powell, K. A., Liu, Z., Hunt, W. H., and Young, S. A.: Overview of the CALIPSO mission and CALIOP data processing algorithms, J. Atmos. Ocean. Tech., 26, 2310-2323, 2009.

Winker, D. M.: Accounting for multiple scattering in retrievals from space lidar, Proc. SPIE 5059, 12th International Workshop on Lidar Multiple Scattering Experiments, 128 (April 7, 2003) doi:10.1117/12.512352, 2003.

Young, S. and Vaughan, M.: The retrieval of profiles of particulate extinction from cloud-aerosol lidar infrared pathfinder satellite observations (CALIPSO) data: algorithm description, J. Atmos. Ocean. Tech., 26, 1105-1119, 2009.

Yu, H., Chin, M., Winker, D. M., Omar, A. H., Liu, Z., Kittaka, C., and Diehl, T.: Global view of aerosol vertical distributions from CALIPSO lidar measurements and GOCART simulations: regional and seasonal variations, J. Geophys. Res., 115, D00H30, doi:10.1029/2009JD013364, 2010.

Zarzycki, C. M. and Bond, T. C.: How much can the vertical distribution of black carbon affect its global direct radiative forcing?, Geophys. Res. Lett., 37, L20807, doi:10.1029/2010GL044555, 2010.

Zhu, A., Ramanathan, V., Li, F., and Kim, D.: Dust plumes over the Pacific, Indian, and Atlantic oceans: climatology and radiative impact, J. Geophys. Res., 112, D16208, doi:10.1029/2007JD008427, 2007. 